\title{
əThe Emergence of the North Icelandic Jet and Its Evolution from Northeast Iceland to Denmark Strait
}

\author{
STEFANIE SEMPER AND KJETIL VÅGE \\ Geophysical Institute, University of Bergen, and Bjerknes Centre for Climate Research, Bergen, Norway \\ ROBERT S. PICKART \\ Woods Hole Oceanographic Institution, Woods Hole, Massachusetts \\ HÉðINN VALDIMARSSON \\ Marine and Freshwater Research Institute, Reykjavík, Iceland \\ DANIEL J. TORRES \\ Woods Hole Oceanographic Institution, Woods Hole, Massachusetts \\ STEINGRÍMUR JÓNSSON \\ Marine and Freshwater Research Institute, Reykjavík, and University of Akureyri, Akureyri, Iceland
}

(Manuscript received 9 April 2019, in final form 12 July 2019)

\begin{abstract}
The North Icelandic Jet (NIJ) is an important source of dense water to the overflow plume passing through Denmark Strait. The properties, structure, and transport of the NIJ are investigated for the first time along its entire pathway following the continental slope north of Iceland, using 13 hydrographic/velocity surveys of high spatial resolution conducted between 2004 and 2018. The comprehensive dataset reveals that the current originates northeast of Iceland and increases in volume transport by roughly $0.4 \mathrm{~Sv}\left(1 \mathrm{~Sv} \equiv 10^{6} \mathrm{~m}^{3} \mathrm{~s}^{-1}\right)$ per $100 \mathrm{~km}$ until $300 \mathrm{~km}$ upstream of Denmark Strait, at which point the highest transport is reached. The bulk of the NIJ transport is confined to a small area in $\Theta-S$ space centered near $-0.29^{\circ} \pm 0.16^{\circ} \mathrm{C}$ in Conservative Temperature and $35.075 \pm 0.006 \mathrm{~g} \mathrm{~kg}^{-1}$ in Absolute Salinity. While the hydrographic properties of this transport mode are not significantly modified along the NIJ's pathway, the transport estimates vary considerably between and within the surveys. Neither a clear seasonal signal nor a consistent link to atmospheric forcing was found, but barotropic and/or baroclinic instability is likely active in the current. The NIJ displays a double-core structure in roughly $50 \%$ of the occupations, with the two cores centered at the 600 - and $800-\mathrm{m}$ isobaths, respectively. The transport of overflow water $300 \mathrm{~km}$ upstream of Denmark Strait exceeds $1.8 \pm 0.3 \mathrm{~Sv}$, which is substantially larger than estimates from a year-long mooring array and hydrographic/velocity surveys closer to the strait, where the NIJ merges with the separated East Greenland Current. This implies a more substantial contribution of the NIJ to the Denmark Strait overflow plume than previously envisaged.
\end{abstract}

\section{Introduction}

Plumes of cold, dense overflow water spill across gaps in the Greenland-Scotland Ridge from the Nordic Seas to the North Atlantic. They form the lower limb

¿ Denotes content that is immediately available upon publication as open access.

Corresponding author: Stefanie Semper, stefanie.semper@uib.no of the Atlantic Meridional Overturning Circulation (AMOC), which is of key importance for the poleward transport of heat in the Atlantic Ocean. Approximately half of the overflow crossing the Greenland-Scotland Ridge passes through Denmark Strait and supplies the densest water to the Deep Western Boundary Current

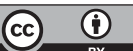

This article is licensed under a Creative Commons Attribution 4.0 license (http://creativecommons.org/ licenses/by/4.0/)

DOI: 10.1175/JPO-D-19-0088.1 
(Jochumsen et al. 2017; Østerhus et al. 2019). As such, determining the formation processes and pathways of the Denmark Strait Overflow Water (DSOW) is necessary to further our understanding of the overturning in the Nordic Seas, and hence the AMOC.

Cooper (1955) was the first to recognize the climatic importance of the dense overflow through Denmark Strait. Subsequent studies suggested that DSOW can be formed in the interior basins of the Iceland and Greenland Seas, where winter cooling leads to openocean convection to intermediate depths (Swift et al. 1980; Swift and Aagaard 1981; Strass et al. 1993). The idea of open-ocean convection forming overflow water in the interior basin of the Iceland Sea was later dismissed in part since there was no known direct pathway from the basin to Denmark Strait. Mauritzen (1996) proposed instead that warm, saline Atlantic Water was gradually transformed into DSOW within the boundary current system of the Nordic Seas and the Arctic Ocean. This scheme implies that the East Greenland Current (EGC) advects most of the DSOW into Denmark Strait, whereas the interior basins of the Greenland and Iceland Seas contribute only to a limited extent. Studies based on quasi-synoptic measurements (Rudels et al. 2002), historical data (Eldevik et al. 2009), chemical tracers (Tanhua et al. 2005), and high-resolution numerical simulations (Köhl et al. 2007) corroborated the notion that the EGC is the main source of overflow water to Denmark Strait.

The transport of DSOW through the 650-m-deep passage in Denmark Strait is estimated to be 3.2$3.5 \mathrm{~Sv}\left(1 \mathrm{~Sv} \equiv 10^{6} \mathrm{~m}^{3} \mathrm{~s}^{-1}\right.$; Harden et al. 2016; Jochumsen et al. 2017). It is relatively constant on decadal time scales and does not exhibit a dominant seasonal cycle (Jochumsen et al. 2017). By contrast, the overflow varies substantially on short time scales (e.g., Harden et al. 2016; Almansi et al. 2017). In particular, different mesoscale processes have been identified using in situ data and numerical models. Large lenses of weakly stratified water called boluses pass through the deepest part of the sill every few days (Mastropole et al. 2017; Almansi et al. 2017). Interspersed with these are intermittent periods of enhanced flow characterized by a very thin overflow layer, referred to as pulses (von Appen et al. 2017). Occasionally the current at the sill reverses and warm water flows northward through the strait. Spall et al. (2019) argued that all of these high-frequency processes are associated with baroclinic instability of the hydrographic front in the strait.

There are two primary water masses comprising the DSOW. The water noted above, transported by the rim current in the Nordic Seas, is referred to as Atlantic-origin water. This is because there is a direct advective link between this relatively warm and saline water and the subpolar North Atlantic south of the Greenland-Scotland Ridge. The second type of overflow water mass is referred to as Arctic-origin water. This water has been transformed in the interior basins of the Nordic Seas via convective overturning, and, as such, it is colder and fresher than Atlantic-origin water. While other water masses are contained within the overflow water mix (e.g., Jeansson et al. 2008), the relative percentages of these constituents appear to be small (Mastropole et al. 2017). Based on previous studies (e.g., Swift and Aagaard 1981; Våge et al. 2013), overflow water colder than $0^{\circ} \mathrm{C}$ is referred to as Arctic-origin water, while that warmer than $0^{\circ} \mathrm{C}$ is considered Atlantic-origin water.

These two water masses are transported into Denmark Strait by a system of currents (Fig. 1). The EGC is the main source of Atlantic-origin water. It accounts for approximately two-thirds of the total volume transport (Harden et al. 2016). The current bifurcates north of Blosseville Basin and continues toward Denmark Strait as the shelfbreak and separated branches of the EGC (Våge et al. 2013). The former flows along the Greenland shelf break, whereas the latter is located farther offshore, near the base of the Iceland slope (Håvik et al. 2017a).

The other current advecting overflow water into Denmark Strait is the North Icelandic Jet (NIJ). The NIJ transports the coldest and densest portion of DSOW along the continental slope north of Iceland (Våge et al. 2011; Harden et al. 2016). The narrow $(15-20 \mathrm{~km})$ current is centered near the $650-\mathrm{m}$ isobath and has a velocity maximum at middepth (Jónsson and Valdimarsson 2004; Våge et al. 2011). The final current in Denmark Strait is the North Icelandic Irminger Current (NIIC), which transports warm and saline Atlantic water northward into the Iceland Sea (Fig. 1). North of Iceland this surface-intensified current shares a common front with the NIJ when the bathymetry brings the currents into close proximity (Pickart et al. 2017).

The discovery of the NIJ by Jónsson (1999) and Jónsson and Valdimarsson (2004) has led to a renewed focus on the Iceland Sea as source for DSOW. Since then, observational, theoretical, and modeling studies have been carried out to enhance our understanding of the NIJ and its role in the Iceland Sea circulation. Using data from multiple shipboard surveys, Våge et al. $(2011,2013)$ demonstrated that the current is a distinct source of dense water to the Denmark Strait overflow plume. This was further verified by Harden et al. (2016) using measurements from a year-long mooring array approximately $200 \mathrm{~km}$ north of the sill. 


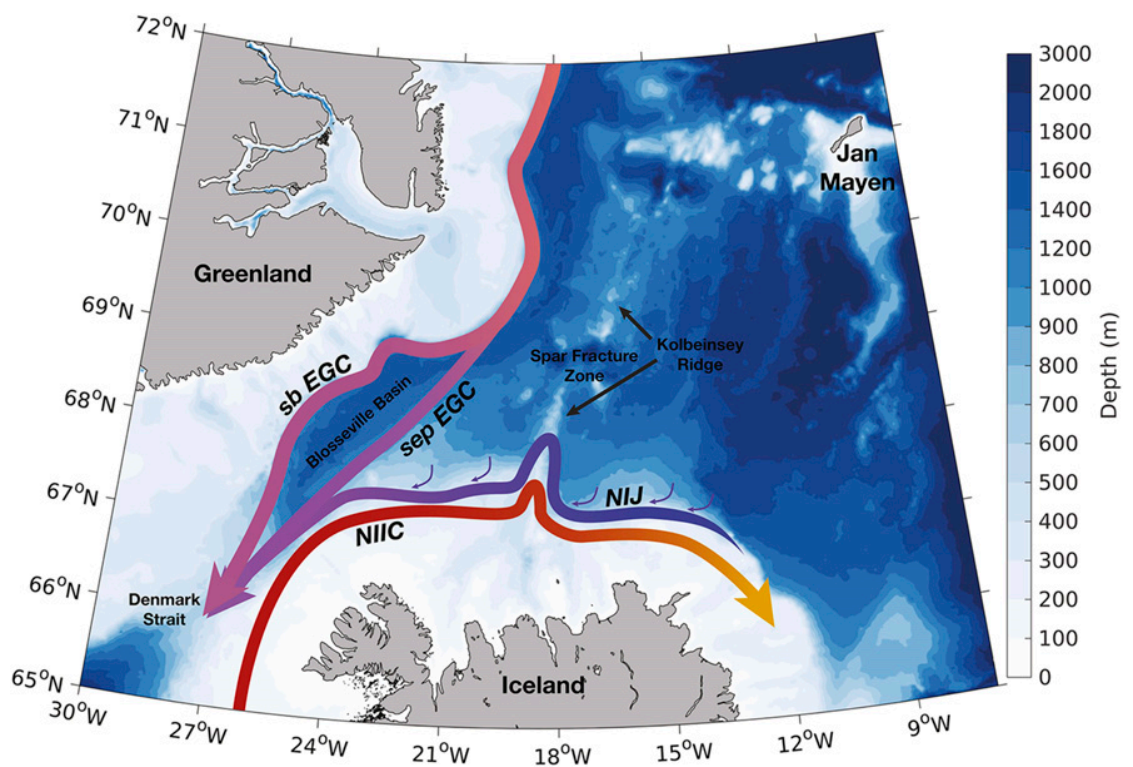

FIG. 1. Schematic circulation in the vicinity of Denmark Strait. The acronyms are: NIIC $=$ North Icelandic Irminger Current, NIJ $=$ North Icelandic Jet, sb EGC $=$ shelfbreak East Greenland Current, sep EGC = separated East Greenland Current. The colored shading is the bathymetry from ETOPO1 (Amante and Eakins 2009).

They estimated that the NIJ contributes roughly onethird of the total DSOW volume transport, and that it merges with the separated EGC north of Denmark Strait. Various modeling studies also show the existence of the NIJ, both in simplified configurations (e.g., Våge et al. 2011; Yang and Pratt 2014), and in more complex general circulation models (e.g., Behrens et al. 2017; Ypma et al. 2019).

The seasonal variability in the NIJ appears to be small. No seasonal cycle is apparent in the velocity time series from three years of moored current meters on the Iceland slope upstream of Denmark Strait (Jónsson 1999). Harden et al. (2016) noted only a slight reduction in transport of the NIJ during winter and spring from their year-long moored records at the same location. Behrens et al. (2017) also found little variability in the volume transport of the current on seasonal to interannual time scales in their model study, while Huang et al. (2019) determined that month-to-month variation of the NIJ strength is significantly correlated with air-sea buoyancy forcing north of Iceland. They explained this connection via the mechanism presented by Spall et al. (2017), in which convection on the continental slope of an island leads to cyclonic flow around the island. On shorter time scales (days to a week), the flow on the Iceland slope north of the sill is very energetic. Harden and Pickart (2018) argued that this is the signature of topographic Rossby waves forced by the meandering of the separated EGC farther offshore. Huang et al. (2019) showed that there is a strong conversion from mean potential energy to eddy energy at the same location, implying that the NIJ is baroclinically unstable as well.

Recently, de Jong et al. (2018) questioned the existence of the NIJ east of the Kolbeinsey Ridge, an extension of the mid-Atlantic Ridge north of Iceland (Fig. 1). They used RAFOS floats to investigate the subsurface circulation in the Iceland Sea, but did not find a connection between the flow east and west of the ridge. However, many of the floats deployed by de Jong et al. (2018) grounded on the continental slope north of Iceland. Substantial vertical velocities indicate the presence of a bottom Ekman layer, presumably caused by the NIJ, which has also been related to the rising of isopycnals due to cold, dense water banking up on the slope (Jónsson and Valdimarsson 2004). This was possibly the reason for the grounding of the floats.

It has been hypothesized that the NIJ is the lower limb of a local overturning loop north of Iceland that involves water mass transformation in the Iceland Sea. According to the idealized simulation of Våge et al. (2011), Atlantic Water in the NIIC is fluxed into the Iceland Sea by eddies, and the water is subsequently transformed due to air-sea heat loss. The resulting dense water progresses back toward the boundary and sinks, feeding the NIJ. Lagrangian trajectories from a high-resolution numerical model corroborate the importance of water mass transformation 
TABLE 1. The scientific cruises, survey times, and occupied transects analyzed in this study. The transects are listed from west to east (Fig. 2). The acronyms are: $\mathrm{KG}=$ Kögur, $\mathrm{HB}=$ Hornbanki, SI $=$ Siglunes, $\mathrm{KR}=$ Kolbeinsey Ridge, $\mathrm{SL}=\mathrm{Slétta}, \mathrm{LN}=\mathrm{Langanes}$ Northeast, and LE = Langanes East.

\begin{tabular}{|c|c|c|c|c|c|c|c|c|c|}
\hline Ship & Month & Year & KG & HB & SI & $\mathrm{KR}$ & SL & $\mathrm{LN}$ & LE \\
\hline RRS James Clark Ross & August & 2004 & $\mathrm{x}$ & & & & & & \\
\hline R/V Knorr & October & 2008 & $\mathrm{x}$ & $\mathrm{x}$ & & $\mathrm{x}$ & & & \\
\hline R/V Bjarni Samundsson & August & 2009 & $\mathrm{x}$ & $\mathrm{x}$ & $\mathrm{x}$ & & $\mathrm{x}$ & $\mathrm{x}$ & \\
\hline R/V Bjarni Scemundsson & February & 2011 & $\mathrm{x}$ & $\mathrm{x}$ & $\mathrm{x}$ & & $\mathrm{x}$ & $\mathrm{x}$ & $\mathrm{x}$ \\
\hline R/V Knorr & September & 2011 & $\mathrm{x}$ & $\mathrm{x}$ & & $\mathrm{x}$ & $\mathrm{x}$ & $\mathrm{x}$ & \\
\hline R/V Bjarni Samundsson & February & 2012 & $\mathrm{x}$ & $\mathrm{x}$ & $\mathrm{x}$ & & $\mathrm{x}$ & $\mathrm{x}$ & $\mathrm{x}$ \\
\hline RRS James Clark Ross & August & 2012 & $\mathrm{x}$ & $\mathrm{x}$ & & & & & \\
\hline R/V Bjarni Samundsson & February & 2013 & $\mathrm{x}$ & $\mathrm{x}$ & $\mathrm{x}$ & & $\mathrm{x}$ & $\mathrm{x}$ & $\mathrm{x}$ \\
\hline R/V Bjarni Samundsson & August & 2015 & $\mathrm{x}$ & $\mathrm{x}$ & & $\mathrm{x}$ & $\mathrm{x}$ & $\mathrm{x}$ & $\mathrm{x}$ \\
\hline R/V Håkon Mosby & August & 2016 & & & & & $\mathrm{x}$ & $\mathrm{x}$ & \\
\hline R/V Bjarni Samundsson & August & 2017 & $\mathrm{x}$ & $\mathrm{x}$ & $\mathrm{x}$ & & $\mathrm{x}$ & $\mathrm{x}$ & $\mathrm{x}$ \\
\hline NRV Alliance & February & 2018 & & & & $\mathrm{x}$ & & & \\
\hline R/V Kristine Bonnevie & June & 2018 & & & & $\mathrm{x}$ & $\mathrm{x}$ & $\mathrm{x}$ & \\
\hline
\end{tabular}

in the Iceland Sea and the boundary current system north of Iceland for the formation of the NIJ (Behrens et al. 2017). However, this hypothesized local overturning loop has not been verified by observations, and details regarding the origin and underlying dynamics of the NIJ remain unclear.

One open question regards the supply of dense water to the NIJ. Water transformed in the Iceland Sea regularly exceeds the minimum potential density of DSOW (Våge et al. 2015), which is $\sigma_{\theta}=27.8 \mathrm{~kg} \mathrm{~m}^{-3}$ (Dickson and Brown 1994). The deepest and densest mixed layers have been found in the northwestern Iceland Sea, where enhanced heat loss offshore of the ice edge can intensify convection (Våge et al. 2015, 2018). However, Våge et al. (2015) and Pickart et al. (2017) argued that water mass transformation in the Iceland Sea may not be sufficient to account for the densest portion of the NIJ $\left(\sigma_{\theta}>28.03 \mathrm{~kg} \mathrm{~m}^{-3}\right)$. They suggested instead that this portion may originate from the Greenland Sea, where sufficiently dense waters are regularly formed (e.g., Strass et al. 1993; Brakstad et al. 2019). While a tracer release study indicated export of dense water from the Greenland Sea to the Iceland Sea within 1.5 years (Messias et al. 2008), the exact time scales and pathways of this possible source for water in the NIJ remain unknown.

In this study we use an extensive collection of shipboard data, obtained during multiple cruises over multiple years, to advance our understanding of the NIJ. We compile hydrographic/velocity sections of high spatial resolution of the NIJ at seven different transects across the continental slope north of Iceland. In doing so, we determine the origin of the current and confirm its existence as an independent, major source of dense water to the Denmark Strait overflow. We provide robust estimates of the volume transport, and characterize the current's properties, thus quantifying the spatial evolution of the hydrography and velocity of the NIJ for the first time along its entire pathway.

\section{Data and methods}

\section{a. Shipboard measurements}

The high-resolution hydrographic and velocity measurements analyzed in this study were collected during 13 shipboard surveys between 2004 and 2018, four of them during winter (Table 1). The surveys included seven transects across the northern slope of Iceland (Fig. 2). Six of the transects are repeated monitoring sections maintained by the Marine and Freshwater Research Institute of Iceland (MFRI), with extra stations added to better resolve the narrow NIJ. The typical station spacing of approximately $5 \mathrm{~km}$ over the slope is comparable to the Rossby radius of deformation in the Iceland Sea (4-5 km; Nurser and Bacon 2014). In the paper we refer to the individual transects by their MFRI section names (Table 1 and Fig. 2). For three of the surveys an alternative transect situated between the Kolbeinsey Ridge and the Slétta transect was sampled instead. We projected these stations onto the original bathymetry of the Slétta transect when constructing mean sections, but retained the bathymetry at the sampled location for transport calculations.

Some of the sections in our collection have been used in previous studies. Eight of the occupations at the Kögur transect were used by Pickart et al. (2017) to investigate the relationship between the NIIC and the NIJ. The mean properties at the Hornbanki transect provided the basis for the model validation in the study of Zhao et al. (2018). In addition, Våge et al. (2011), Våge et al. (2013), and Pickart et al. (2017) 


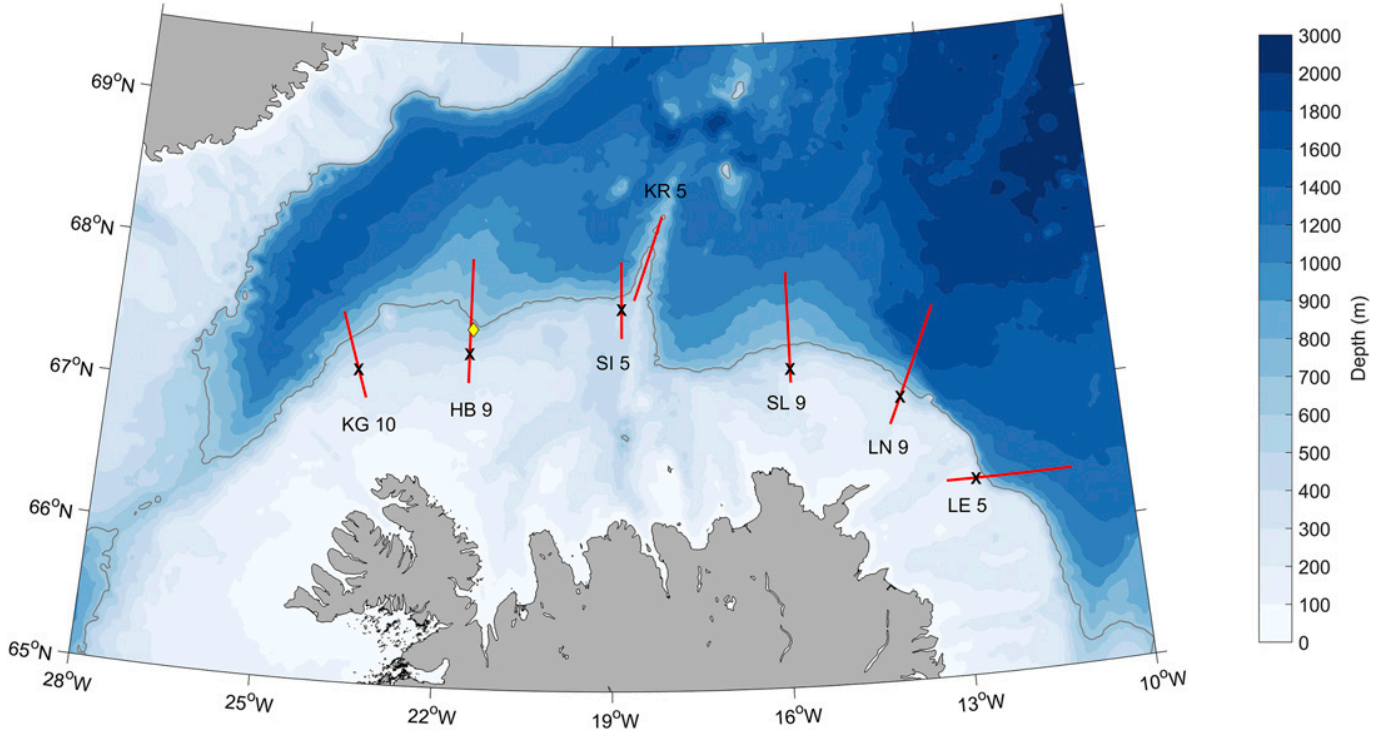

FIG. 2. Shipboard transects used in the study (red lines). The location of the shelf break at each line is indicated by the black crosses. The acronyms and numbers denote the transect names (KG $=$ Kögur, $\mathrm{HB}=$ Hornbanki, $\mathrm{SI}=$ Siglunes, $\mathrm{KR}=$ Kolbeinsey Ridge, $\mathrm{SL}=$ Slétta, $\mathrm{LN}=$ Langanes Northeast, $\mathrm{LE}=$ Langanes East $)$ and the number of occupations for each transect, respectively. The location of the mooring at the Hornbanki section is indicated by the yellow diamond. The bathymetry is shaded, and the $650-\mathrm{m}$ isobath is highlighted by the gray contour

included individual occupations from various transects in their studies.

The hydrographic data on all of the cruises were obtained using a Sea-Bird 911+ conductivity-temperaturedepth (CTD) instrument. The CTD was mounted on a rosette with Niskin bottles to collect water samples, which were used to calibrate the conductivity sensor. The resulting accuracy of the CTD measurements is $0.3 \mathrm{dbar}$ for pressure, $0.001^{\circ} \mathrm{C}$ for temperature, and $0.002 \mathrm{~g} \mathrm{~kg}^{-1}$ for salinity (Våge et al. 2011). Velocities were measured using acoustic Doppler current profiler (ADCP) instruments. On three of the cruises (RRS James Clark Ross 2004, R/V Knorr 2008, NRV Alliance 2018), a vessel-mounted ADCP (VMADCP) was used, while an upward- and downward-facing lowered ADCP (LADCP) system mounted on the rosette was utilized on the remaining surveys. The VMADCP data on the R/V Knorr 2008 and NRV Alliance 2018 cruises were acquired using the University of Hawaii Data Acquisition System (UHDAS) and the VMDAS collection software (Teledyne RDInstruments), respectively. Subsequently, these data were processed using the Common Ocean Data Access System (CODAS; Firing and Hummon 2010). On the RRS James Clark Ross 2004 cruise, VMADCP data were collected and processed using a custom data acquisition system unique to the ship (Pstar system). The LADCP data were processed using the LADCP Processing Software Package from the Lamont-Doherty Earth Observatory (Thurnherr 2010, 2018). Following the processing, the barotropic tides were removed from all of the velocity datasets by applying an updated version of the regional tidal model of Egbert and Erofeeva (2002), which has a resolution of $1 / 60^{\circ}$.

Using Laplacian-spline interpolation (Pickart and Smethie 1998), we constructed $2 \mathrm{~km} \times 10 \mathrm{~m}$ gridded fields of Conservative Temperature and potential density anomaly referenced to the sea surface, as well as Absolute Salinity (hereafter referred to as temperature, density, and salinity, respectively). We followed the TEOS-10 standard (IOC et al. 2010), which differs by on average 0.167 for Absolute Salinity compared to practical salinity for the hydrographic properties of the NIJ. The temperature difference is smaller than the accuracy of the measurements, and the potential density in TEOS-10 is $O(0.001) \mathrm{kg} \mathrm{m}^{-3}$ greater than in ITS-90. Typical CTD stations indicating the station spacing in the mean sections were identified from the mean distances between the stations. Because the sections were truncated in order to display the same horizontal scale, there is not always a marker at the end of the sections; we have not extrapolated the data for more than two grid points.

We deviated from the normal interpolation routine for the two following situations. First, stations that were separated by more than $11 \mathrm{~km}$ (usually located 


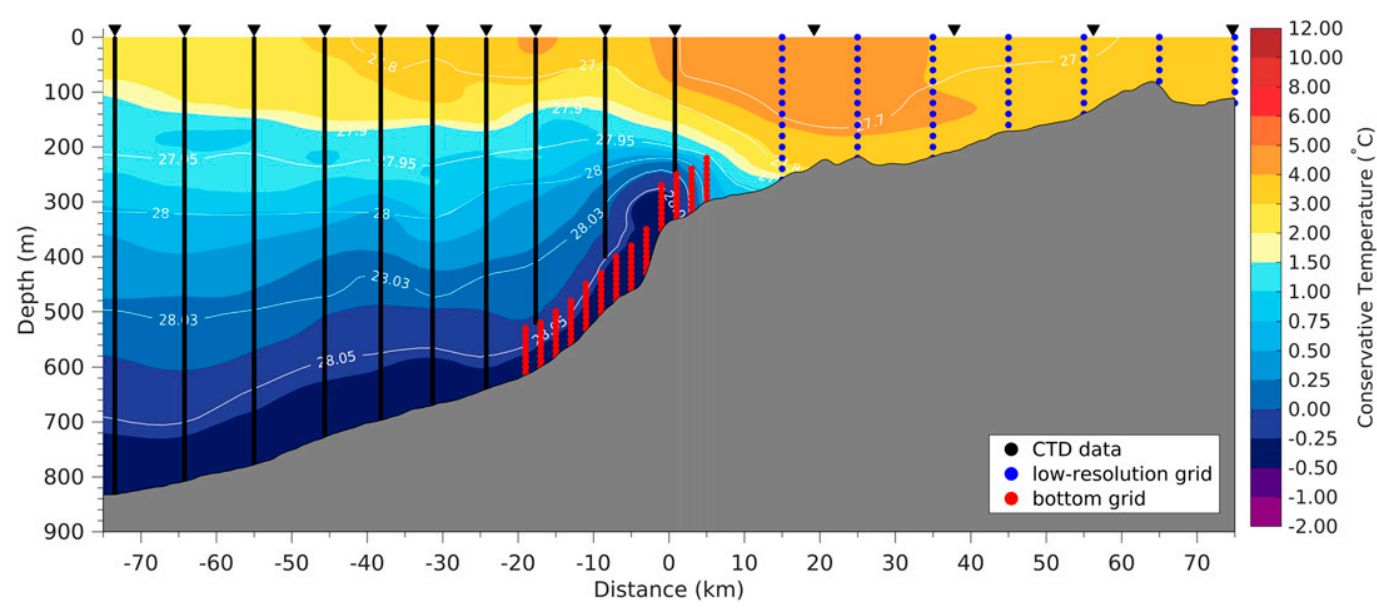

FIG. 3. Example of an occupation (Hornbanki, February 2013) with dense water residing at the shelf break. The CTD stations are indicated by black triangles. The stations on the shelf are separated by more than $11 \mathrm{~km}$, so there the low-resolution grid was applied first (resulting in the blue data points). On the slope, the bottom grid was used (red dots). The low-resolution grid and bottom grid data were then combined with the remaining high-resolution CTD data (black dots), resulting in the final gridded temperature (color) and density (contours) sections. The cold, dense bottom layer of water along the slope is maintained using this multistep gridding routine.

on the shelf) were interpolated onto a low-resolution grid of $10 \mathrm{~km} \times 20 \mathrm{~m}$. This grid and the remaining, closer-spaced station data were then reinterpolated onto the final, high-resolution grid. Second, we employed a combined interpolation approach for occupations where very dense water $\left(\sigma_{\theta} \geq 28.03 \mathrm{~kg} \mathrm{~m}^{-3}\right)$ was observed at the shelf break, in order to conserve the structure of the dense water banked up on the slope. In those sections, we interpolated the data first with respect to depth (depth grid, following the standard interpolation routine) and then with respect to height above the bottom (bottom grid). The bottom grid was used up to $100 \mathrm{~m}$ above the bottom at the steepest part of the slope where the dense water was present, while the depth grid was used for the remainder of the section. At the boundaries of the two grids, interpolation was used to ensure a smooth transition. An example in which both of these additional interpolation routines were applied is shown in Fig. 3.

Sections of absolute geostrophic velocity, normal to each transect, were calculated as follows. First, we constructed $2 \mathrm{~km} \times 10 \mathrm{~m}$ gridded sections of the crosstrack ADCP velocities. Next, we computed the relative geostrophic velocity at each section using the hydrographic fields. At each grid point of the section, the depth-averaged relative geostrophic velocity was then matched to the corresponding depth-averaged ADCP velocity. The top and bottom $50 \mathrm{~m}$ were excluded for grid points with bottom depths greater than $200 \mathrm{~m}$, in order to avoid surface and bottom boundary layers. The along-stream direction $x$ is taken to be positive toward Denmark Strait, where distances between transects were calculated following the 650-m isobath (Fig. 2). For each transect the origin (distance $y=0 \mathrm{~km}$ ) was placed at the shelf break (except for the Kolbeinsey Ridge transect where the latitude of the shelf break at the nearby Siglunes transect was chosen as zero distance). Positive velocities are directed toward Denmark Strait.

The absolutely referenced geostrophic velocity sections were used to estimate the volume transports of the NIJ. The error associated with the volume transport is proportional to the area of the NIJ and estimated from a combination of instrument error and inaccuracies in the tidal model. Våge et al. (2011) estimated the combined uncertainty associated with the LADCP/VMADCP systems and the processing routine to be $3 \mathrm{~cm} \mathrm{~s}^{-1}$, while they assessed the uncertainty of the tidal model to be $2 \mathrm{~cm} \mathrm{~s}^{-1}$ northwest of Iceland because of inaccuracies in bathymetry and relatively strong tidal currents. Although the tidal model performs slightly better northeast of Iceland, we conservatively assume the same error as for the western transects. An additional source of error arises from the transport calculation at the Kögur section (Fig. 2), where the NIJ at times is difficult to distinguish from the separated EGC (Harden et al. 2016). For each of these occupations, we distinguish the currents based on the differently sloping isopycnals and the subsurface salinity maximum of the separated EGC, which is not present in the NIJ (Harden et al. 2016). The differences between this "best-estimate" boundary, and a maximum and a minimum limit, are included in the total error for these occupations. Finally, we also increase the uncertainty of the transport for occupations where the current is not fully 
covered by the observations. We then estimate the missing transport and include both this additional transport and its uncertainty estimated from the instrument and tidal errors to the uncertainty of the transport of the entire occupation.

\section{b. Moored measurements}

We use data from a current meter mooring deployed from 23 August 2005 to 10 August 2006, situated $19 \mathrm{~km}$ north of the shelf break at the Hornbanki transect $\left(67^{\circ} 30.4516^{\prime} \mathrm{N}\right.$ and $21^{\circ} 32.1410^{\prime} \mathrm{W}$, Fig. 2). The instrument was an Aanderaa RCM-7, sampling hourly, which was placed at $360-\mathrm{m}$ depth on the $620-\mathrm{m}$ isobath. It thus provided a year-long time series of temperature, pressure, and velocity in the center of the NIJ. The velocity data were de-tided using the T_TIDE package (Pawlowicz et al. 2002) and rotated into the along- and across-stream directions associated with the Hornbanki transect. Following our convention above, positive along-stream velocities $u$ are directed toward Denmark Strait.

\section{c. Atmospheric data}

To assess the wind field during the period of the mooring deployment, and its possible influence on the NIJ, we use the ERA-Interim reanalysis data from the European Centre for Medium-Range Weather Forecast (ECMWF; Dee et al. 2011). This weather prediction model, with an effective horizontal resolution of $80 \mathrm{~km}$, assimilates meteorological data to approximate the atmospheric state every six hours. ERA-Interim reanalysis data have been shown to be accurate in our study region (Harden et al. 2011). Here we use the 6-hourly mean sea level pressure and $10-\mathrm{m}$ wind field in the region across $0^{\circ}-45^{\circ} \mathrm{W}$ and $55^{\circ}-75^{\circ} \mathrm{N}$ for the period of the mooring deployment. We also consider the data from the grid point closest to the mooring as well as one grid point directly north of Denmark Strait (at the same latitude farther west).

\section{Mean hydrography and velocity}

The mean absolute geostrophic velocity sections for each transect (Fig. 4) offer the first robust view of the NIJ along the entire continental slope north of Iceland. Using data from two of the 13 surveys considered here, Våge et al. (2011) noted that the NIJ was weak at their northeasternmost transect (the Langanes Northeast section). This was consistent with the weakened NIJ in their idealized model in this part of the domain. The emergence and strengthening of the NIJ toward Denmark Strait occurring simultaneously with the disintegration of the NIIC toward northeast Iceland was representative of the model's
Iceland Sea overturning loop. Our data allow us to quantify the presence of the NIJ between Denmark Strait and northeast Iceland.

Starting at the easternmost section, Langanes East, a weak flow directed toward Denmark Strait is present near the shelf break in two of the five occupations. In the mean, however, the NIJ is not present at this transect (Fig. 4a). At the Langanes Northeast transect, $94 \mathrm{~km}$ farther downstream, velocities toward Denmark Strait were observed in each of the occupations (Fig. 4b). At times two cores of the current were present, although the flow was generally quite weak $\left(<5 \mathrm{~cm} \mathrm{~s}^{-1}\right.$ in the mean). Our data thus corroborate the notion by Vage et al. (2011) that the NIJ emerges somewhere between these two transects on the northeast slope of Iceland. At the Slétta transect, $94 \mathrm{~km}$ farther downstream, the existence of several cores becomes evident in the mean, and the current velocities are greater (Fig. 4c). The flow becomes even stronger and broadens where it crosses the Kolbeinsey Ridge (Fig. 4d). At the Siglunes transect, immediately downstream of the Kolbeinsey Ridge, the typical structure of the NIJ is more pronounced. In particular, the deep isopycnals slope upward and the shallow isopycnals slope downward toward the shelf break, leading to the characteristic middepth intensification of the current (Fig. 4e). Here only one core of the NIJ was observed in each occupation. Farther downstream at the Hornbanki transect, the NIJ exhibits again two cores in the mean (Fig. 4f). The core near the shelf break is strongest, with velocities approaching $15 \mathrm{~cm} \mathrm{~s}^{-1}$. Between the two cores, the flow is in the opposite direction.

The last section presented here is the Kögur transect, where the NIJ at times merges with the surface-intensified separated EGC (Harden et al. 2016). Some of the EGC is visible in the westernmost part of the mean section (Fig. 4g). Using two years of mooring data from the Kögur transect, Huang et al. (2019) determined that there were three basic configurations of the flow on the Iceland slope: a strong separated EGC on the midslope, distinct from a weak NIJ farther upslope; a scenario where the two currents are merged; and a case where a strong NIJ is located near the 650-m isobath, its mean position in the moored time series, with a very weak signature of the separated EGC farther offshore. At times this latter scenario can persist close to Denmark Strait (R. Pickart 2019, unpublished data). At the sill, however, the separated EGC and NIJ appear to be fully merged, with the cold Arctic-origin water of the NIJ occupying the deepest part of the sill (Mastropole et al. 2017).

In all of the mean sections except the Kolbeinsey Ridge transect (which is located farther offshore than the others, Fig. 2), the surface-intensified NIIC is present 


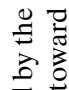

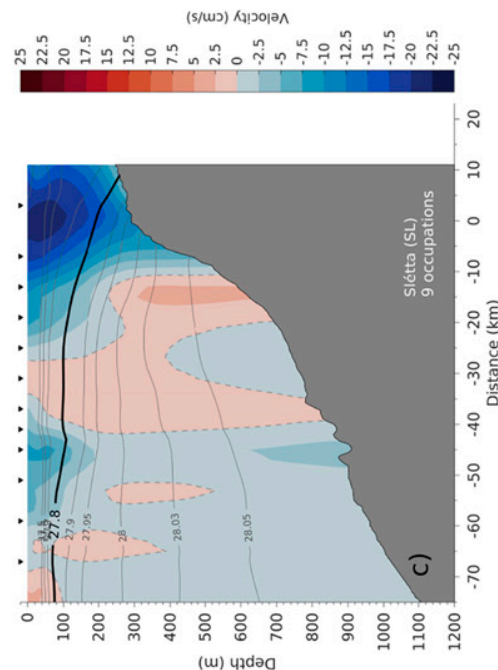

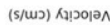

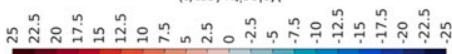

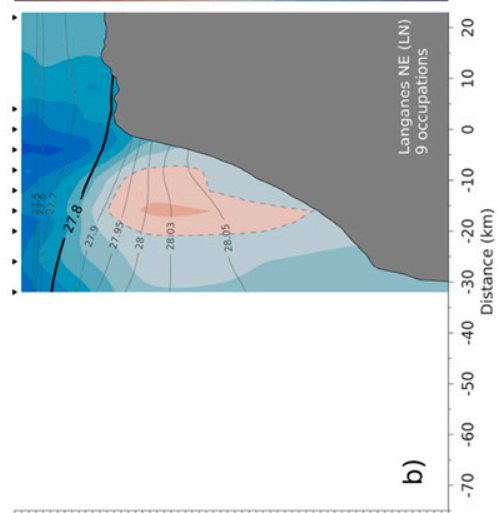

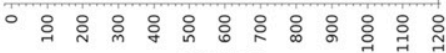
(w) ч)वəo

(s/พว) Кำวоำ

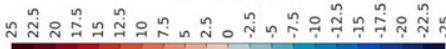

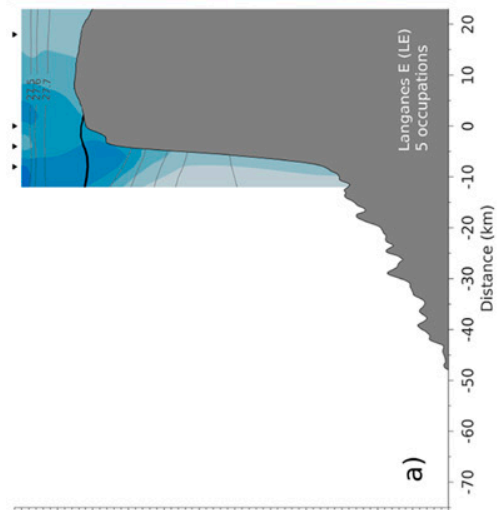

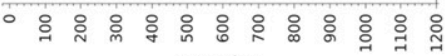
(w) чиवа

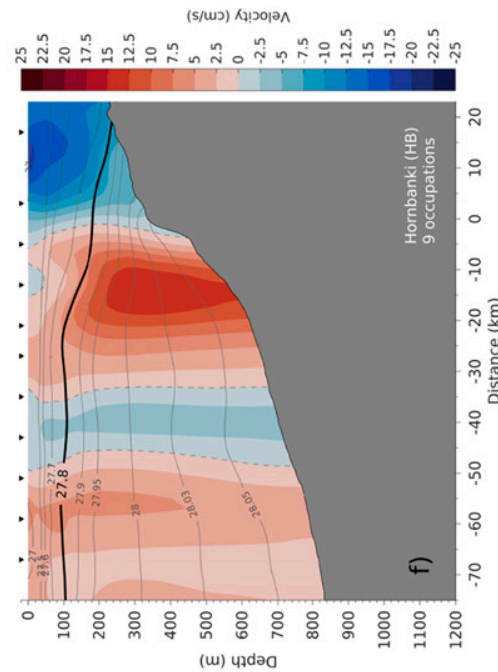

(s/wว) Кำวํำ

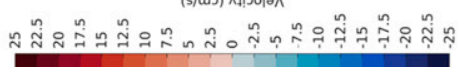

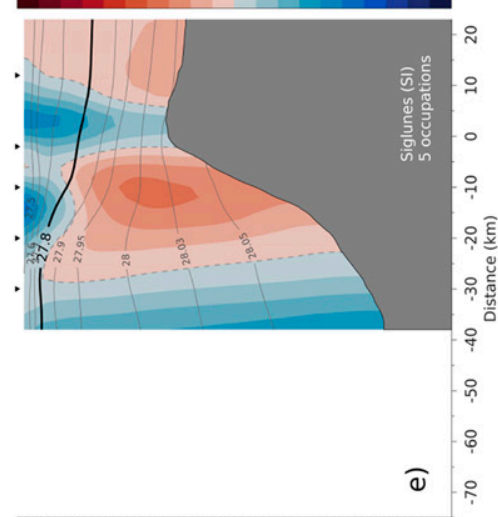

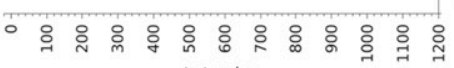
(w) udगa

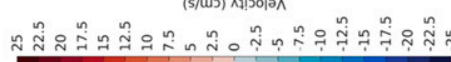

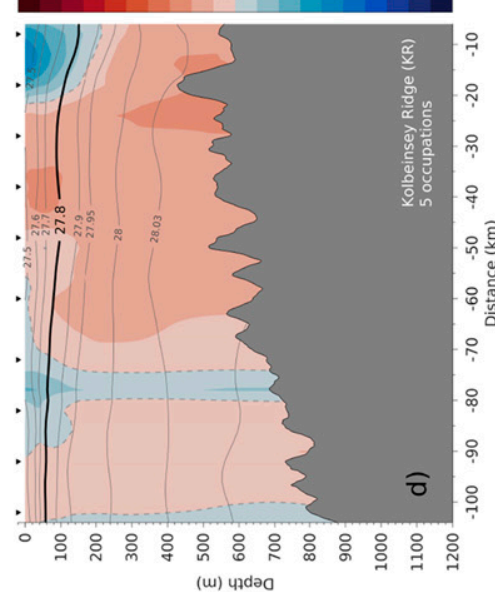

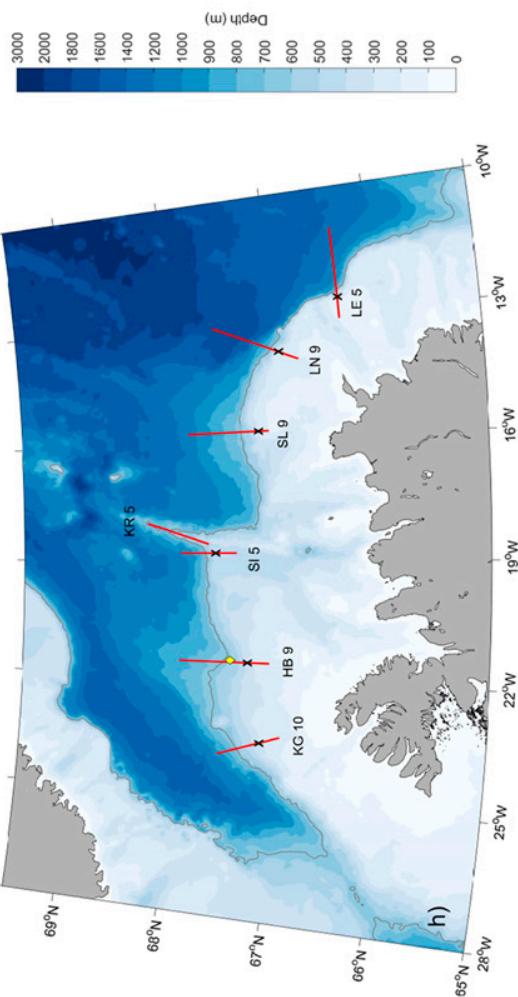

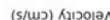

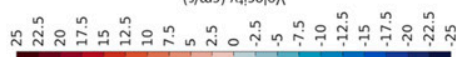

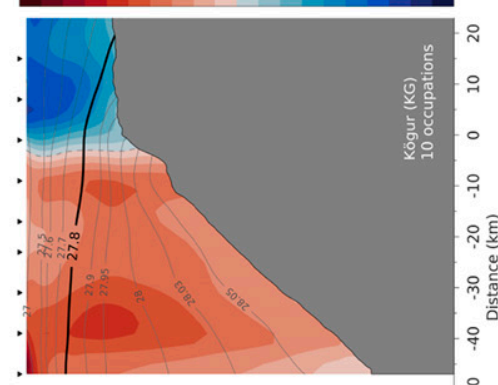

ธิ

○ \&
䂧

施:

:D

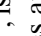

'

我 $\frac{0}{0}$

i

$\Lambda:$

80

$\vec{b}$.

J.

远

은

记.

उप छू

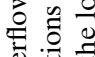

8

응.

긍

定

들

윙 잔

记

$\dot{0} \stackrel{\square}{\square}$

zo

:

प के

密

वृ

들

:

공

ठ

氜

嵌

$\Xi$

궁

흘 츨

릉

든

흐

讨

긍

?로

홍

$\triangle 0$

\%

롱

ते छ

สิ 0

宓青导

की

ब당

ㄱ․

它 
inshore of the NIJ flowing in the opposite direction. Notably, this is in contrast to the notion put forth by Våge et al. (2011) in which the NIIC disintegrates in concert with the NIJ progressing clockwise around the island. While we are unable to fully assess the NIIC transport with our data, since some of the sections do not capture the shoreward end of the current, we note that the mean transport of the core of the NIIC at the Langanes Northeast section is $0.85 \mathrm{~Sv}$. This is half of the $1.7 \mathrm{~Sv}$ of NIIC transport at the Kögur transect estimated by Pickart et al. (2017). Hence, at the location where the NIJ first emerges on the northeast Iceland slope, the NIIC is still strong. Recently, Ypma et al. (2019) also called into question the direct connection between the NIIC and the NIJ via the local Iceland Sea overturning loop. Although substantial water mass transformation took place north of Iceland in their numerical simulations, the contribution of the NIIC to the DSOW was small.

The front separating the NIJ and NIIC is evident from the mean hydrographic sections (Figs. 5 and 6). In particular, the saline water of the NIIC is present inshore of the front at each site except for the Kolbeinsey Ridge section (Fig. 6). We note that at some of the transects, particularly the Kögur and Hornbanki sections, a layer of warm water extends well offshore of the shelf break (Fig. 5). Pickart et al. (2017) discussed this feature and demonstrated that at times, the NIJ was located adjacent to the temperature front at the seaward edge of this layer, instead of the NIIC front. This is seen to be the case for the offshore NIJ core at the mean Kögur section. It is also occasionally true for individual realizations of the offshore core at the different transects. In Figs. 4-6 we have highlighted the $27.8 \mathrm{~kg} \mathrm{~m}^{-3}$ isopycnal, which slopes downward toward the shelf break and grounds on the outer shelf at most of the transects. This implies that the bulk of the overflow water is found seaward of the shelf break.

\section{Double-core structure of the NIJ}

The double-core structure of the NIJ, evident from the mean sections of absolute geostrophic velocity presented above, was previously noted by Pickart et al. (2017). They identified a second core of the NIJ in all of their winter occupations at the Kögur transect. When this offshore core was present, it was larger and stronger than the inshore core near the shelf break. We find that the double-core structure is not limited to the Kögur transect. The core locations identified from the individual realizations of the Hornbanki and Slétta sections, west and east of the Kolbeinsey Ridge, respectively, are shown in Fig. 7. Any outer cores that were not entirely bracketed by the observations are not included. In all nine occupations of the Hornbanki transect, the inner core was situated near the shelf break at the $600-\mathrm{m}$ isobath at distance $y=-20 \mathrm{~km}$. The outer core was present in six of the nine occupations. Its position varied slightly more than that of the inner core, and was found at the 800-m isobath in five of these occupations (Fig. 7).

At the Slétta transect, east of the Kolbeinsey Ridge, the inner and outer cores were again centered at the 600- and 800-m isobaths, respectively. However, there was more cross-stream variation in the positions of both cores at this site. This could be due to the fact that the continental slope is steeper east of the Kolbeinsey Ridge, which results in a narrower NIJ. The distance between the inner and outer cores is approximately $17 \mathrm{~km}$ here compared to approximately $43 \mathrm{~km}$ at the transect west of the Kolbeinsey Ridge. Farther downstream, at the Kögur transect near Denmark Strait, the inner core appeared to be diverted higher onto the continental slope (near $400 \mathrm{~m}$, Fig. 4g). We note, however, that this is likely not always the case. As discussed above, using the Kögur mooring array data, Huang et al. (2019) demonstrated that when the separated EGC is strong, the NIJ tends to be located on the upper continental slope. By contrast, when the separated EGC is weak (or absent), the NIJ is located near the $600-\mathrm{m}$ isobath. We do not have enough shipboard realizations to investigate this definitively.

The double-core structure of the NIJ can also be identified from the mean current vectors computed using the repeat LADCP/VMADCP data (Fig. 8, where the currents are averaged between $100 \mathrm{~m}$ and the bottom). At both the Hornbanki and the Slétta transects, the vectors were generally directed toward the west following the bathymetry with cores near the $600-$ and $800-\mathrm{m}$ isobaths. The mean current vector at $360-\mathrm{m}$ depth from the year-long mooring deployment at the Hornbanki transect west of the Kolbeinsey Ridge agrees well with the depth-averaged ADCP current vectors in magnitude and direction. Hence, the average of our nine synoptic shipboard surveys appears to be representative of the mean conditions.

The double-core structure of the NIJ appears to be a frequent feature of the current, with a second core present in roughly $50 \%$ of all occupations. The depth of the velocity maximum of the outer core is generally shallower in the water column (ranging from 200 to $400 \mathrm{~m}$ ) compared to that of the inner core (ranging from 200 to $600 \mathrm{~m}$ ). The temperature and salinity properties of the cores varied little within each occupation and did not show a systematic difference between the inner and outer cores. While Pickart et al. (2017) observed the second NIJ core only in the wintertime occupations of the Kögur transect, where it was stronger than the inner core, we did not identify any consistent seasonal variability in our more extensive dataset. At present it is unknown why the NIJ is 


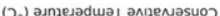

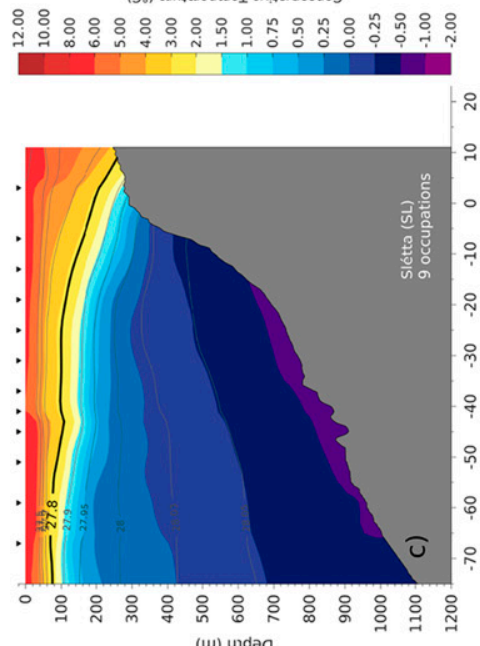
(u) पวdəa

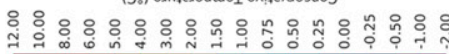

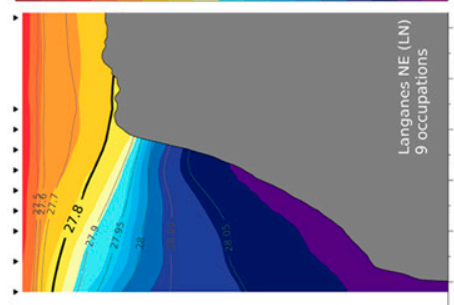

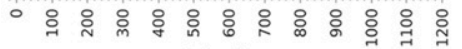

(u) प’dəa

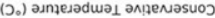

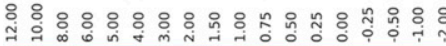

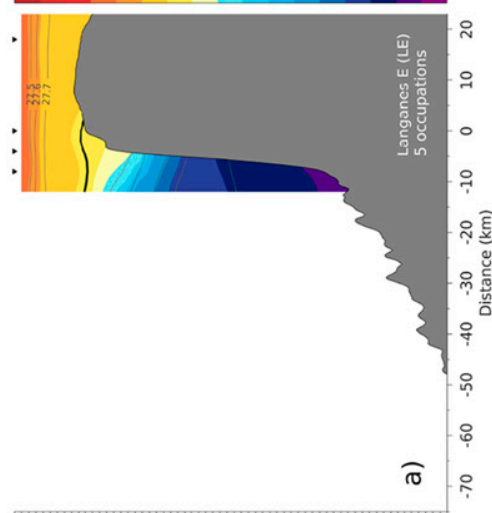

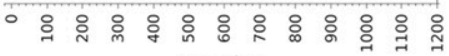
(u) 4 ᄀa

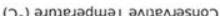

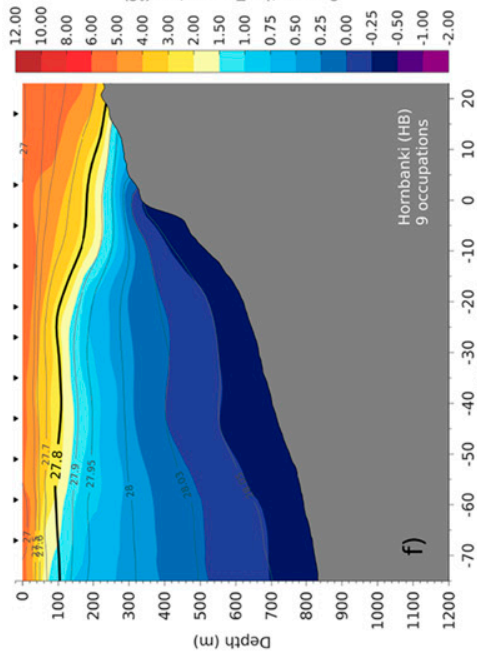

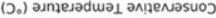

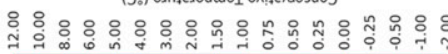

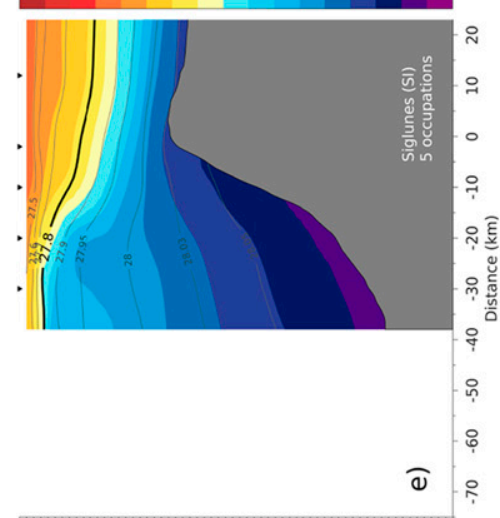

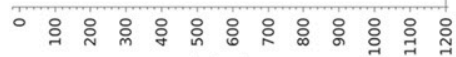

(u) पวdə0

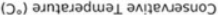

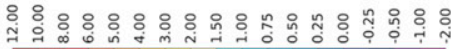

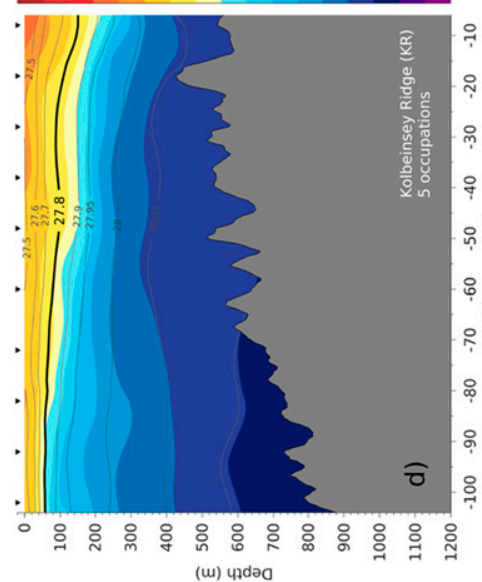

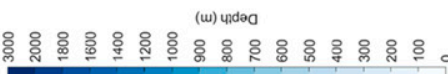
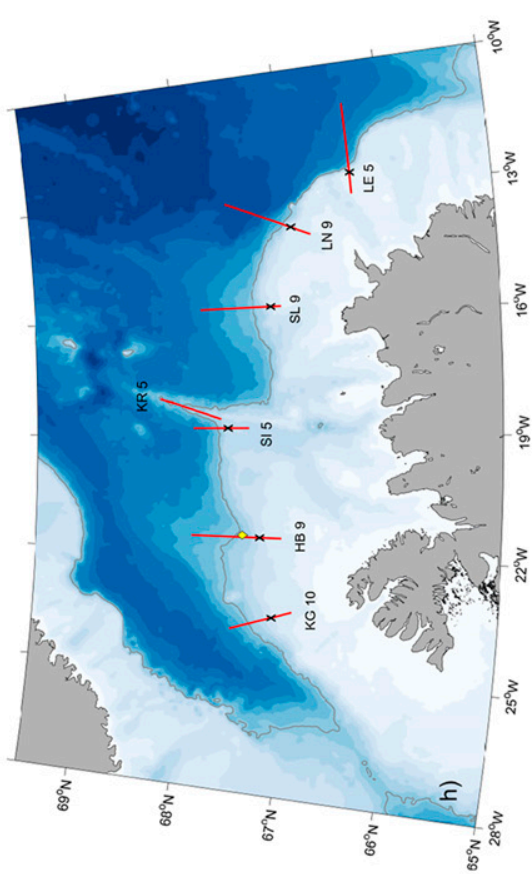

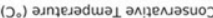

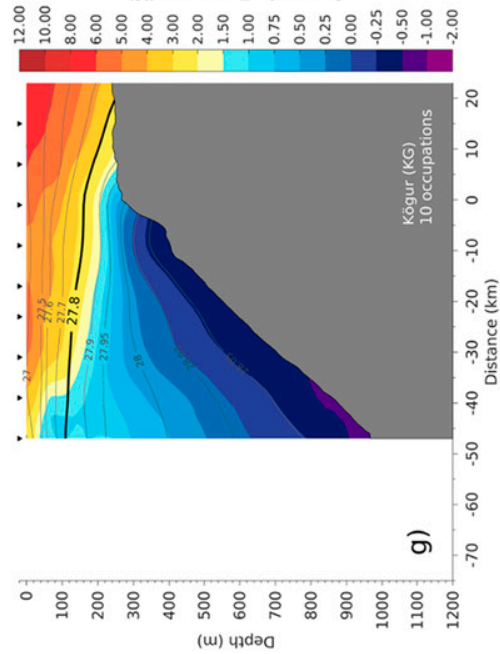




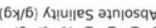

ㅇㅇㅇㅇㅇㅇㅇㅛ

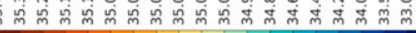

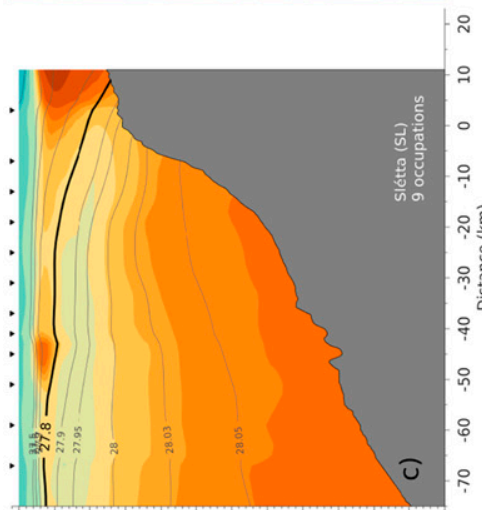

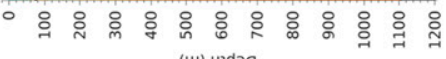
(แ) ч1]dəo

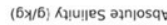

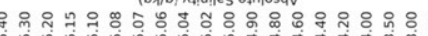

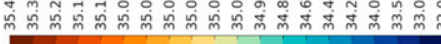

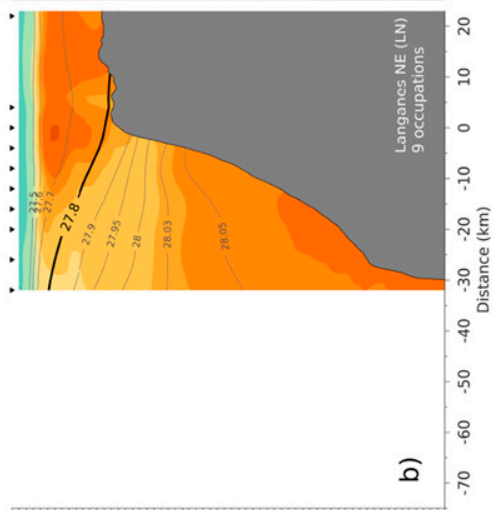

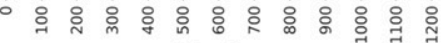
(ui) प1dəo

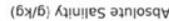

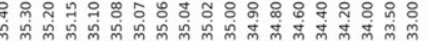

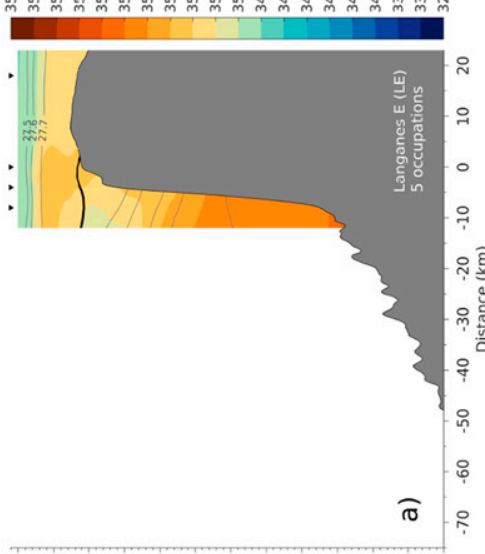

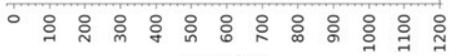
(w) ч)də0

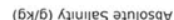

우응
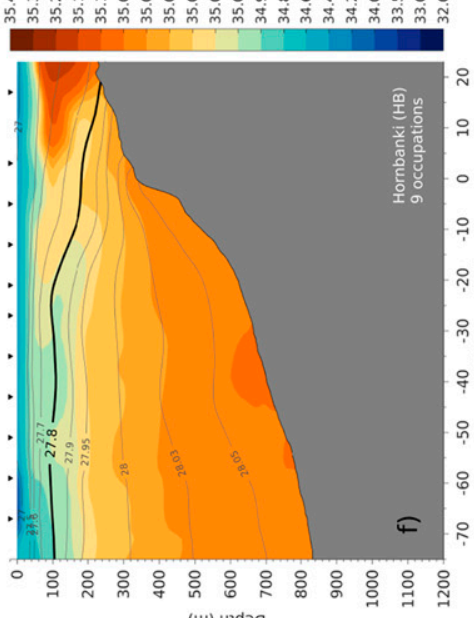
(u) पวdəa

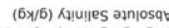

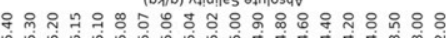

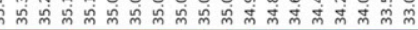

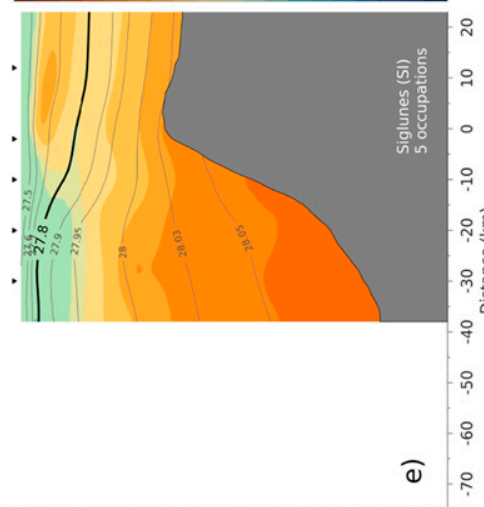

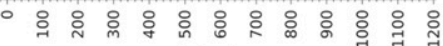
(w) u’dəa

(6x/6) Rzunjes әznjosay

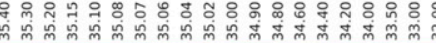

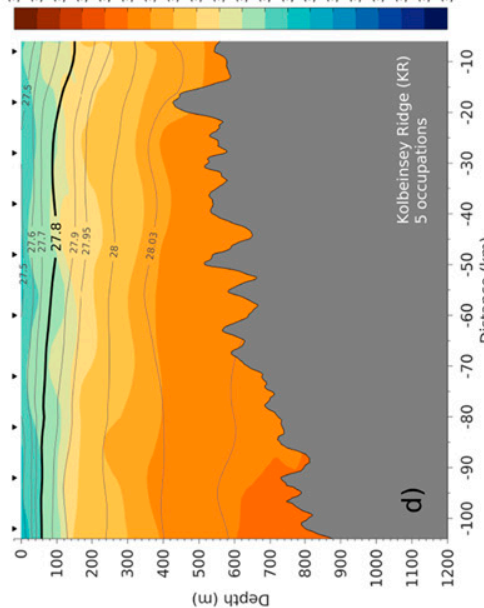

(w) यdida

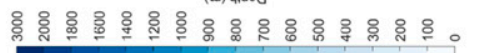
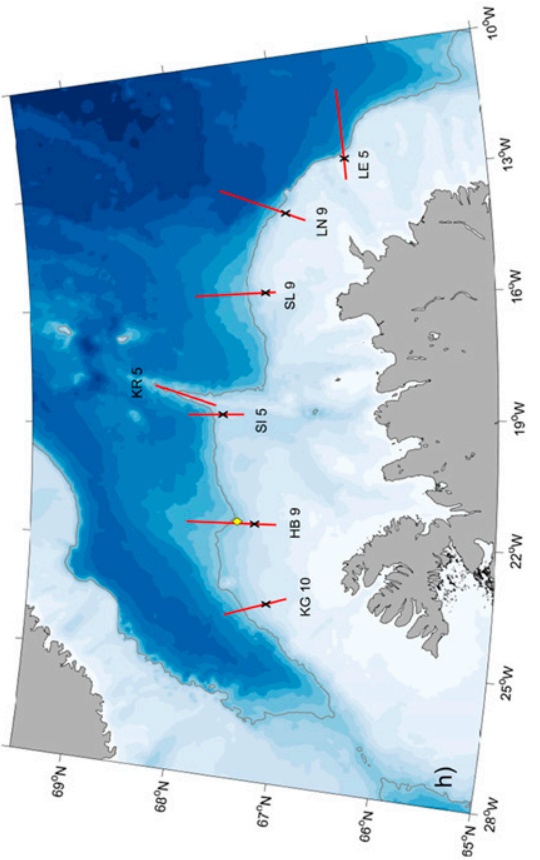

(6x/6) Rilunes әznosar

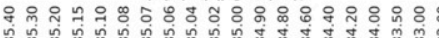

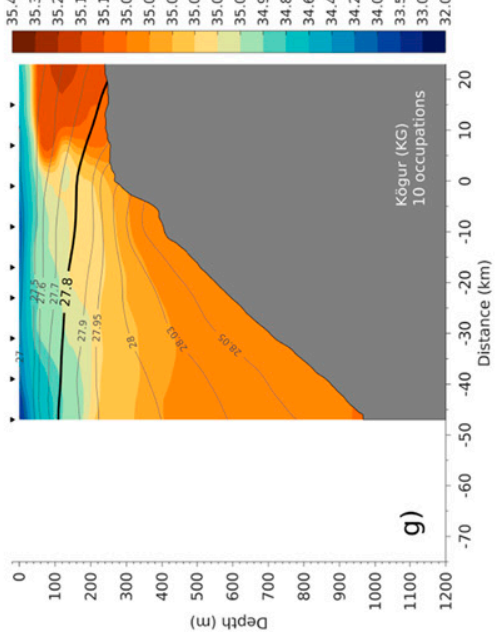



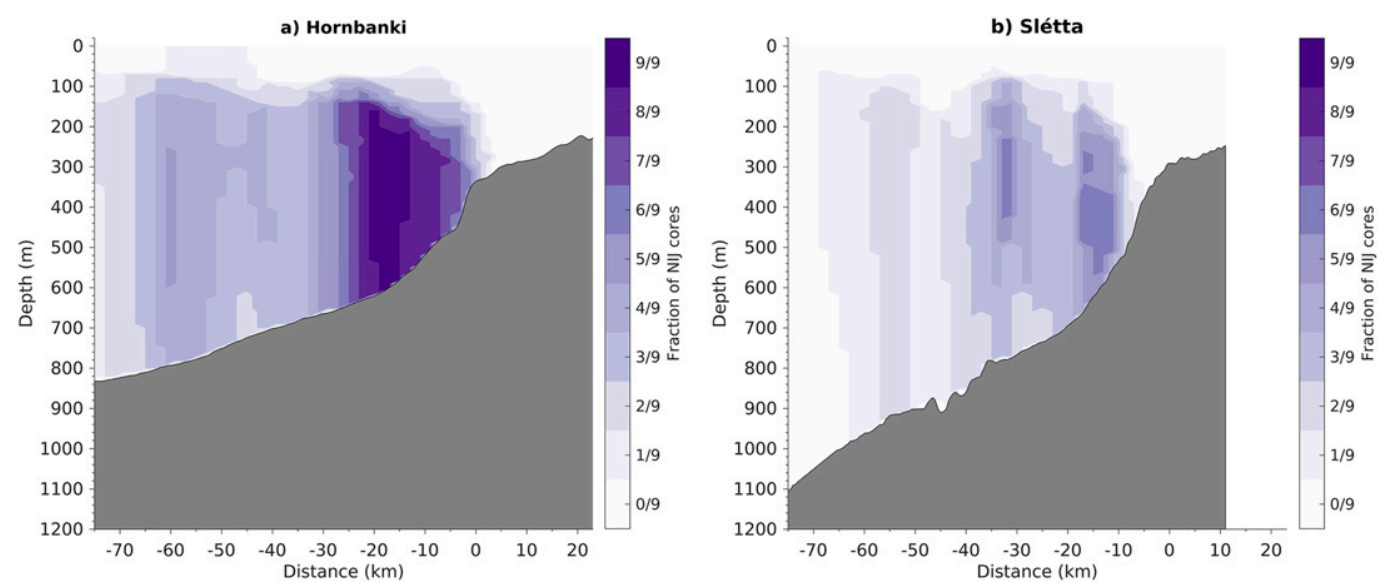

FIG. 7. Overlay of the locations of fully resolved NIJ cores at (a) Hornbanki (west of the Kolbeinsey Ridge) and (b) Slétta (east of the Kolbeinsey Ridge). The color indicates the number of realizations.

filamented in this fashion; we provide some thoughts concerning this in section 7 .

\section{Along-stream evolution}

\section{a. Hydrographic properties}

For each of the six transects where the NIJ was present in the mean (which excludes Langanes East), we constructed a volume transport $\Theta-S$ diagram, which shows the mean volume transport over all occupations of the transect as a function of temperature and salinity. The resulting diagrams for the Slétta and Hornbanki transects are shown in Fig. 9. This revealed that only a very small portion of the water transported by the NIJ is not overflow water. At the Slétta transect, east of the Kolbeinsey Ridge, water lighter than $27.8 \mathrm{~kg} \mathrm{~m}^{-3}$ was very warm (up to $4^{\circ} \mathrm{C}$ ) and saline (Fig. 9b). While the same was true at the Hornbanki transect west of the Kolbeinsey Ridge, there was also cold, fresh water near the surface (Fig. 9a). The total transport was larger at Hornbanki than Slétta, but at both transects the bulk of the transport was limited to a small area in $\Theta-S$ space.

For each of the volume transport $\Theta-S$ diagrams, we defined the locus of the $10 \Theta-S$ classes containing the highest transport as the transport mode of the given section. (The exact number of $\Theta-S$ classes and their extents do not affect the results substantially; we chose divisions of $0.1^{\circ} \mathrm{C}$ in temperature and $0.005 \mathrm{~g} \mathrm{~kg}^{-1}$ in salinity). Considering all six transects, the transport mode is centered near $-0.29^{\circ} \pm 0.16^{\circ} \mathrm{C}$ in temperature and $35.075 \pm 0.006 \mathrm{~g} \mathrm{~kg}^{-1}$ in salinity, corresponding to a density of $\sigma_{\theta}=28.05 \mathrm{~kg} \mathrm{~m}^{-3}$. This demonstrates that the main source waters of the NIJ must be very dense. The cold temperature $\left(<0^{\circ} \mathrm{C}\right)$ classifies the mode as Arctic-origin water. This agrees well with the Kögur mooring time series analyzed by Harden et al. (2016), who found that the NIJ transports water of Arctic origin at depth. By comparison, the EGC carries mostly warmer and lighter water of Atlantic origin (e.g., Håvik et al. 2017a). At Denmark Strait, Arctic-origin water is found in the deepest part of the passage, below water of Atlantic origin (Mastropole et al. 2017).
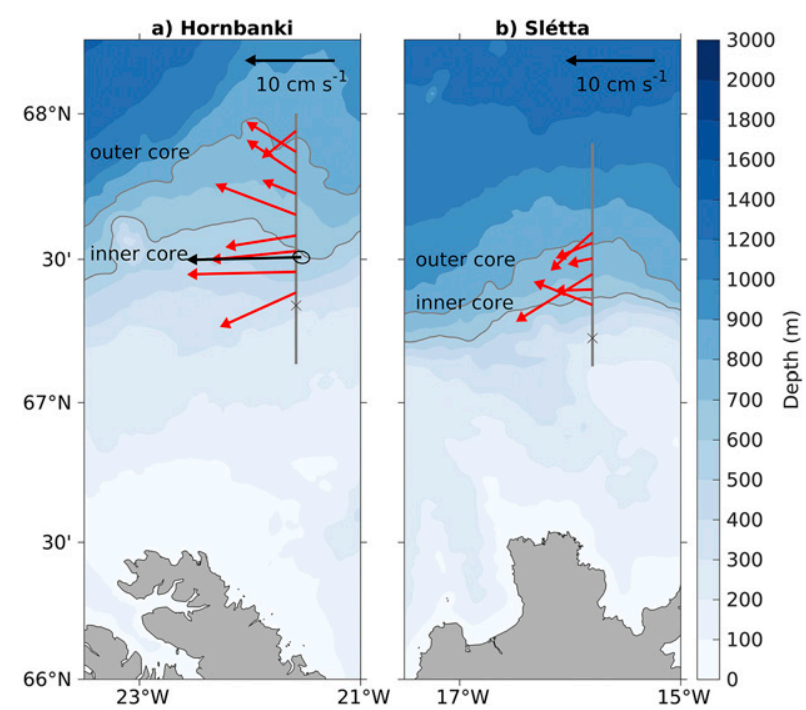

FIG. 8. Mean current vectors (red) for the nine occupations of (a) Hornbanki (west of the Kolbeinsey Ridge) and (b) Slétta (east of the Kolbeinsey Ridge) at the typical stations indicated in Fig. 4. The vectors are averaged between the bottom and 100-m depth, which coincides approximately with the depth of the $27.8 \mathrm{~kg} \mathrm{~m}^{-3}$ isopycnal (Fig. 4). The mean current vector from the year-long mooring record at Hornbanki and its standard error ellipse are shown in black. Black crosses indicate the location of the shelf break. Background colors show bathymetry, and the 600- and 800-m isobaths are highlighted. 

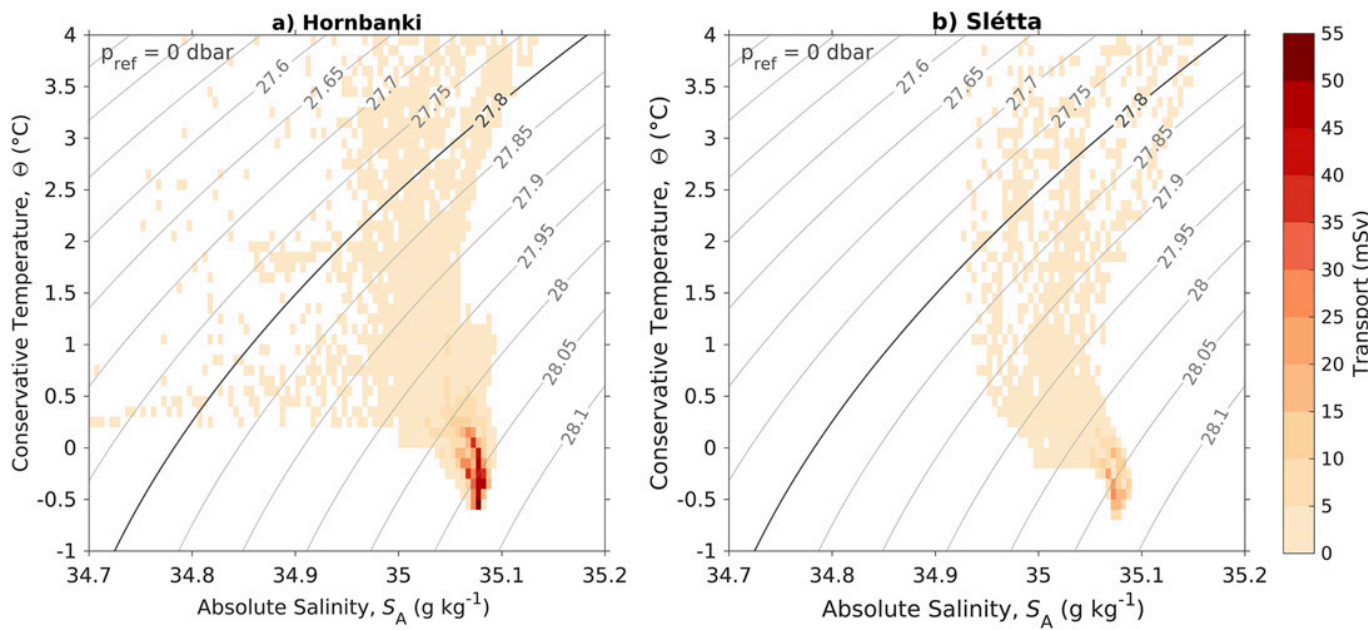

FIG. 9. Mean volume transport of the NIJ as function of temperature and salinity combined from all occupations at the (a) Hornbanki and (b) Slétta transects, west and east of the Kolbeinsey Ridge, respectively. The gray contours represent density, and the $27.8 \mathrm{~kg} \mathrm{~m}^{-3}$ isopycnal is highlighted.

To quantify the evolution of temperature and salinity along the length of the NIJ, we considered the variation of the 10 highest transport $\Theta-S$ classes at each site (Fig. 10). This shows how the hydrographic properties of the bulk of the overflow water are modified toward Denmark Strait. There is no significant linear trend of the median values of the 10 classes (red bars in Fig. 10) at the $95 \%$ confidence level according to the Student's $t$ test, for either temperature or salinity. Since any such trends are based on six values only, we used the bootstrap method to estimate the reliability of these trends. The bootstrap method is based on random sampling with replacement from the dataset and is not constrained by assumptions about the underlying probability distribution (e.g., Emery and Thomson 2014). From 1000 sample combinations chosen randomly from the pool of $\Theta-S$ classes at each transect, there is no true positive or negative trend in the hydrographic
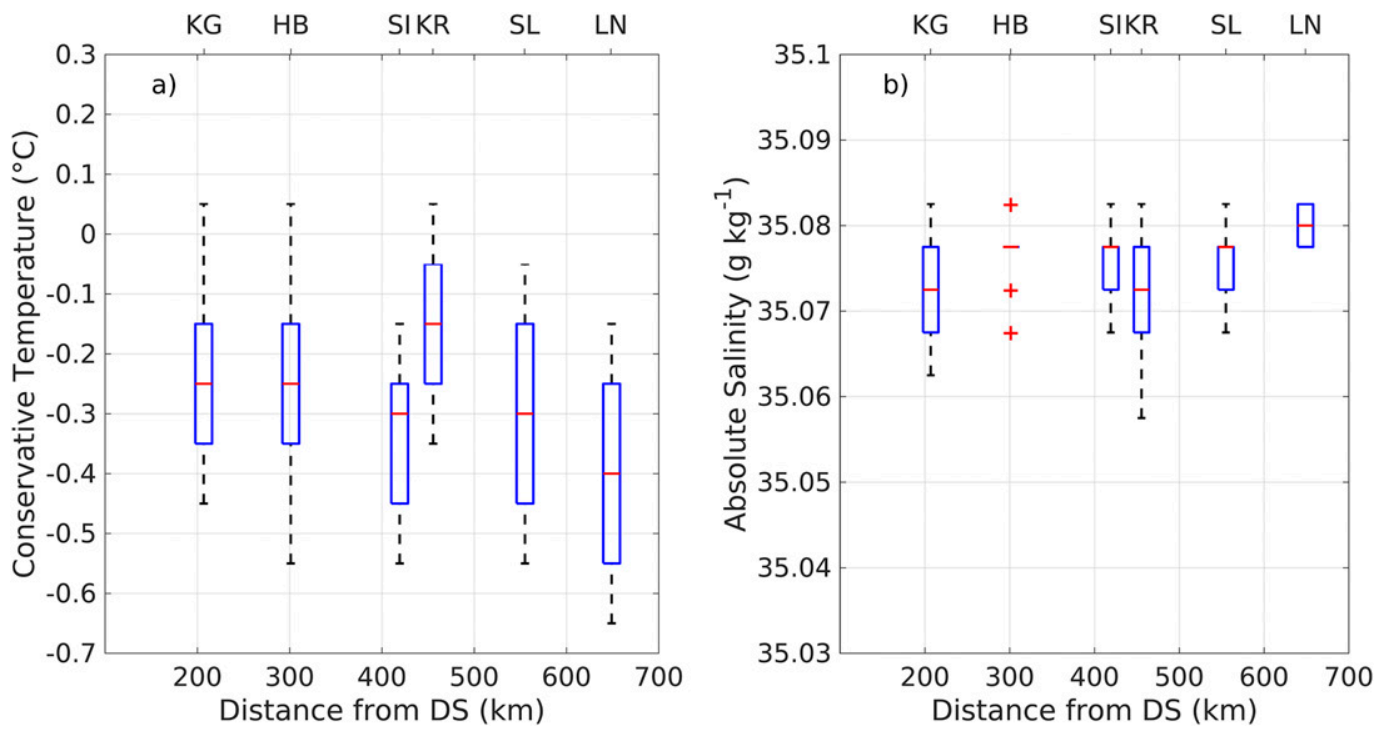

FIG. 10. Along-stream evolution of (a) temperature and (b) salinity for the 10 main transport classes of the NIJ (see text). The 25th and 75th percentiles for each transect are indicated by the blue boxes, and the median value is marked by the red dash. The black dashed lines show the range of values not considered to be outliers, while the red crosses indicate the outliers. The $y$ axis is chosen such that the maximum range corresponds to a change in density of $0.05 \mathrm{~kg} \mathrm{~m}^{-3}$ with constant salinity and temperature for (a) and (b), respectively. The acronyms are: $\mathrm{KG}=\mathrm{Kögur}$, $\mathrm{HB}=$ Hornbanki, SI = Siglunes, $\mathrm{KR}=$ Kolbeinsey Ridge, $\mathrm{SL}=$ Slétta, and LN = Langanes Northeast. 


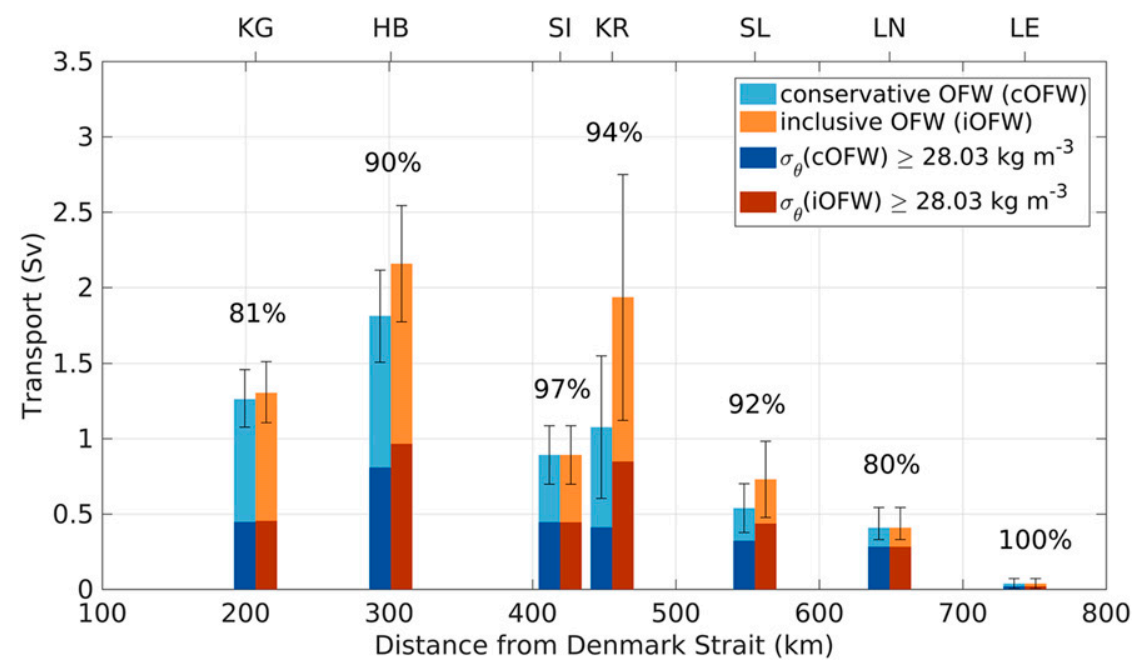

FIG. 11. Mean volume transport of overflow water (OFW) in the NIJ at the different transects, computed as the mean of the individual occupations. For the conservative estimate (cOFW, blue colors), the outer cores that were not fully resolved are ignored. For the inclusive estimate (iOFW, orange colors) the partially resolved outer cores were extrapolated (see text). Also shown is the portion of overflow water denser than $\sigma_{\theta}=28.03 \mathrm{~kg} \mathrm{~m}^{-3}$. The percentage indicates the fraction of overflow water to total transport at each transect. The acronyms are: $\mathrm{KG}=$ Kögur, $\mathrm{HB}=$ Hornbanki, $\mathrm{SI}=$ Siglunes, $\mathrm{KR}=$ Kolbeinsey Ridge, $\mathrm{SL}=$ Slétta, $\mathrm{LN}=$ Langanes Northeast, and LE $=$ Langanes East.

properties at the $95 \%$ confidence level. We therefore conclude that the temperature, salinity, and density of the dominant transport mode of the NIJ are not significantly modified from northeast Iceland to Denmark Strait.

Interestingly, the temperature does exhibit a significant warming trend of approximately $0.1^{\circ} \mathrm{C}$ per $100 \mathrm{~km}$ toward Denmark Strait when considering the evolution of the mean temperature for the entire current (not shown). This implies that some portion of the NIJ warms along its path, possibly due to entrainment of ambient waters which are warmer northwest than northeast of Iceland. However, as demonstrated above, the entrainment does not significantly affect the properties of the dense transport mode.

\section{b. Volume transport}

While the temperature and salinity of the transport mode do not change significantly toward Denmark Strait, the mean velocity sections of Fig. 4 presented earlier indicate that the volume transport does; recall that the NIJ originates between the Langanes East and Langanes Northeast transects. We now present estimates of the overflow water transport at the different transects, computed as the mean of the individual occupations.

For each transect we provide two estimates. The first is based on a conservative approach where we disregarded all outer cores that were not fully resolved. This estimate does not include all of the NIJ and provides a lower transport limit. For the second estimate, we doubled the transport of any outer core that was not fully resolved, with the idea being that the ship sampled roughly half of the core. This value, which we refer to as the inclusive estimate, is more realistic because we know that the full extent of the current was not sampled. In cases when we doubled an outer core that was not fully resolved, a larger uncertainty was assigned (section 2a). The two transport estimates are identical for the three transects where the NIJ was completely resolved.

The volume transport of overflow water increases by on average approximately $0.4 \mathrm{~Sv}$ per $100 \mathrm{~km}$ considering the six transects from Langanes East, northeast of Iceland, to Hornbanki, roughly $300 \mathrm{~km}$ upstream of Denmark Strait (Fig. 11). This trend is significant at the $95 \%$ confidence level according to the Student's $t$ test. We have included the easternmost transect in Fig. 11, even though there is no flow in the mean section (Fig. 4). Our results emphasize that the NIJ emerges in the region northeast of Iceland. Furthermore, overflow water is by far the dominant constituent of the NIJ: the fraction of overflow water to the total transport is on average $90 \%$ for the collection of transects (Fig. 11).

The contribution to the transport from water deeper than $650 \mathrm{~m}$, the approximate depth of the Denmark Strait sill, is comparably small. This portion accounts on average for only $10 \%$ of the transport of overflow 
water. To contribute to the overflow, this water needs to be brought to shallower depths. Harden et al. (2016) showed that there is significant aspiration in Denmark Strait, which is why the deepest portion is included in our transport estimates. However, since the transport associated with this deepest portion is small, we can still compare the transport estimates to previous estimates by Våge et al. (2011) and Våge et al. (2013) who neglected this deep part of the NIJ.

While the transport increases overall toward Denmark Strait, the value decreases between the last two transects (Hornbanki to Kögur, Fig. 11). Observations (Harden et al. 2016) and numerical models (Behrens et al. 2017) show that the NIJ merges with the separated EGC between Hornbanki and Denmark Strait. Some of the water that is transported by the NIJ at Hornbanki may therefore be entrained into the separated EGC farther downstream, and thus is not accounted for in our transport estimates at Kögur. Our estimates for the Kögur transect are $1.3 \pm 0.2 \mathrm{~Sv}$, which agrees well with the $1.4 \pm 0.3$ and $1.23 \pm 0.32 \mathrm{~Sv}$ estimated by Våge et al. (2013) and Pickart et al. (2017), respectively, both of whom took similar approaches for determining the transport using different subsets of the data analyzed here.

Notably, the transport estimates using our synoptic realizations of the Kögur transect are larger than the transport of the NIJ estimated by Harden et al. (2016) using data from the mooring array at that location $(1.00 \pm 0.17 \mathrm{~Sv})$. One possible reason for this discrepancy is that we are presenting only 10 occupations, while the mooring data provided three realizations per day over a year-long period. Another possible reason for the discrepancy is that Harden et al. (2016) calculated net transport between the separated EGC and the Iceland shelf break, while we included only equatorward flow in our transport estimate. As such, these estimates are not directly comparable, and higher transports are expected from our approach. Furthermore, it was often difficult for Harden et al. (2016) to distinguish between the separated EGC and the NIJ. They developed an objective technique for determining the boundaries of these two currents and split the transport in the transition region evenly between them, but there was inherent uncertainty in such a division.

To shed light on this, we examined the gridded velocity sections from the mooring array and assigned a boundary between the separated EGC and the NIJ at each time step guided by the automatically determined separation lines from Harden et al. (2016), but also taking into acccount the differently sloping isopycnals of the two currents. In approximately $20 \%$ of the sections the separated EGC and the NIJ were clearly distinct, while in the remaining realizations the currents were partially or fully merged. The transport of the NIJ estimated for the entire time series based on our boundary and considering equatorward flow only is $1.4 \pm 0.1 \mathrm{~Sv}$, which is in close agreement with our transport from the 10 hydrographic/velocity sections $(1.3 \pm 0.2 \mathrm{~Sv})$. Considering only the subset of sections where the separated EGC and the NIJ were clearly distinct, the NIJ is recognizable as a middepthintensified current. In approximately $40 \%$ of these sections it exhibited a double-core structure. Furthermore, the bulk of the transport had properties similar to the previously identified transport mode. This strongly suggests that our 10 hydrographic/velocity sections are representative of the mean conditions.

The transport of the NIJ for the subset of Kögur mooring sections where the current was distinct was $1.7 \pm$ $0.2 \mathrm{~Sv}$. This is close to our estimate from the Hornbanki transect where the NIJ has not yet started to merge with the EGC. There the transport is $1.8 \pm 0.3 \mathrm{~Sv}$ for the conservative estimate and $2.2 \pm 0.4 \mathrm{~Sv}$ for the inclusive estimate. All things considered, this suggests that the value of Harden et al. (2016) may be an underestimate. In particular, when the NIJ and the EGC are apart, the NIJ has a larger transport. On the other hand, when the currents are merged, some of the water transported by the NIJ may be assigned to the EGC, which would tend to reduce the estimated contribution of the NIJ at the Kögur transect. Our results thus imply a potentially greater role of the NIJ in supplying overflow water to Denmark Strait.

We also present the portion of overflow water transport denser than $\sigma_{\theta}=28.03 \mathrm{~kg} \mathrm{~m}^{-3}$ in Fig. 11. This value represents the bounding isopycnal of the NIJ transport mode discussed in the previous section (Fig. 9). As noted in Våge et al. (2013), water this dense is not found in either the shelfbreak EGC or the separated EGC above sill depth. Furthermore, most boluses passing through Denmark Strait contain water near this density (Mastropole et al. 2017). Våge et al. (2011) computed a transport of $0.6 \pm 0.2 \mathrm{~Sv}$ of this dense water in Denmark Strait, which is comparable to our value of approximately $0.5 \pm 0.1 \mathrm{~Sv}$ for the inclusive estimate at the Kögur transect (Fig. 11).

In general, the transport of water denser than $\sigma_{\theta}=$ $28.03 \mathrm{~kg} \mathrm{~m}^{-3}$ increases toward Denmark Strait and accounts for on average $50 \%$ of the entire overflow transport (Fig. 11). This implies that the NIJ is supplied with dense water along its entire pathway. The model simulation of Vage et al. (2011) suggested that roughly two-thirds of the NIJ is supplied by sinking of dense water along the northern boundary of Iceland, while the remaining third is due to lateral entrainment. 
Alternatively, there could be direct advective sources feeding the NIJ. One possible such source is a southward flow of overflow water that emanates north of the Spar Fracture Zone (Fig. 1) and follows the western side of the Kolbeinsey Ridge. The existence of such a flow has been suggested from RAFOS float tracks (de Jong et al. 2018) and numerical simulations (Behrens et al. 2017). Observations from a year-long mooring deployment close to the Kolbeinsey Ridge also indicated generally southward flow in 2007/08 (Jónsson and Valdimarsson 2012a). However, the mooring was situated near the $1000-\mathrm{m}$ isobath south of the Spar Fracture Zone and hence it may have recorded parts of the NIJ crossing the ridge from the east and not a distinct flow originating from north of the Spar Fracture Zone. From our sections, we can neither confirm nor reject the existence of a southward flow west of the Kolbeinsey Ridge that supplies the NIJ. However, if there is such a current, it would only contribute a minor amount of water to the NIJ, as there is little change in transport between the Kolbeinsey Ridge and Hornbanki transects (Fig. 11).

The origin of the water constituting the densest portion of the NIJ is under debate. Using historical CTD data, Våge et al. (2015) showed that wintertime mixedlayer densities in the Iceland Sea only occasionally exceed $\sigma_{\theta}=28.03 \mathrm{~kg} \mathrm{~m}^{-3}$. This mainly occurs in the northwestern part of the Iceland Sea. (It is worth noting that the data coverage in winter is generally sparse.) In this region, heat loss offshore of the ice edge can intensify convection (Vagge et al.2015), which is facilitated by the removal of fresh surface waters before the onset of winter by northerly winds (Våge et al. 2018). Based on a freshwater budget of the region, Pickart et al. (2017) argued that convection in the northwestern Iceland Sea cannot account for more than half of the water in the NIJ. While water with properties of the densest portion of the NIJ is present throughout the Iceland Sea at greater depths, significant transformation must occur elsewhere.

The Greenland Sea has been suggested as a possible source for the densest portion of the NIJ (Våge et al. 2015; Pickart et al. 2017), where much denser and deeper mixed layers are common (e.g., Strass et al. 1993; Brakstad et al. 2019). For the Greenland Sea gyre, Brakstad et al. (2019) estimated the annual production of waters exceeding $\sigma_{\theta}=28.05 \mathrm{~kg} \mathrm{~m}^{-3}$ to be at least $0.6 \pm 0.5 \mathrm{~Sv}$ for recent winters. This is roughly the same as the amount of water denser than $\sigma_{\theta}=28.03 \mathrm{~kg} \mathrm{~m}^{-3}$ transported by the NIJ, and thus adds credence to the notion that the densest water in the NIJ stems from the Greenland Sea. A tracer release study indicates that rapid export of dense water from the Greenland Sea to the Iceland Sea is possible (Messias et al. 2008), but the exact pathways have not yet been identified.

While the RAFOS floats of de Jong et al. (2018) did not provide any evidence of the NIJ crossing the Kolbeinsey Ridge, we observed clear westward flow across the ridge on all of the occupations of this transect (Fig. 4d). This provides compelling evidence that the NIJ successfully negotiates the ridge as it flows westward. We note, however, that the transport of the current at the Siglunes transect, immediately downstream of the Kolbeinsey Ridge, appears to be anomalously small (i.e., it does not follow the general trend of increasing transport, Fig. 11). This motivates us to investigate the behavior of the NIJ around this sharp ridge using a scaling analysis.

Marshall and Tansley (2001) derived a condition for the separation of a boundary current from the continental slope which has been applied to different cases, including the middepth-intensified flow of Levantine Intermediate Water around Sardinia in the Mediterranean Sea (Bosse et al. 2015) and the flow of Canadian Basin Deep Water around the Morris Jesup Rise in the Arctic Ocean (Björk et al. 2010). Marshall and Tansley (2001) integrated the potential vorticity over an area encompassing the slope and the boundary current and found that the condition for the separation of the boundary current is comprised of three terms related to the planetary $\beta$ effect, vortex stretching of the boundary current when crossing isobaths, and the curvature of the coastline or bathymetry. In our case, the $\beta$ term is small compared to the vortex stretching term and can be neglected. The condition for separation of the current then scales as

$$
r<\left(\frac{U}{f \nabla H / H}\right)^{1 / 2},
$$

where $r$ is the radius of curvature, $U$ is the speed of the boundary current, $f$ is the Coriolis parameter, and $H$ is the depth. The radius of curvature where the NIJ crosses the Kolbeinsey Ridge is $r \approx 4-8 \mathrm{~km}$, while the depth is $H \approx 600-800 \mathrm{~m}$. Using the average speed of $U=$ $4.6 \mathrm{~cm} \mathrm{~s}^{-1}$ as well as the minimum and maximum speeds $\left( \pm 2 \mathrm{~cm} \mathrm{~s}^{-1}\right)$ of the NIJ at the Kolbeinsey Ridge gives a critical $r$ of 5-9 km, which is very similar to the measured radius of curvature. This result suggests that the entire NIJ cannot remain intact when turning south after crossing the ridge, and that only some part of the current is able to make the sharp turn to the Siglunes transect only $36 \mathrm{~km}$ downstream where the transport is lower (Fig. 11). We note that only a single current core has been observed at this transect (Fig. 4e), while the ADCP velocities farther offshore exhibit a southward component (not shown). Such a southward flow 


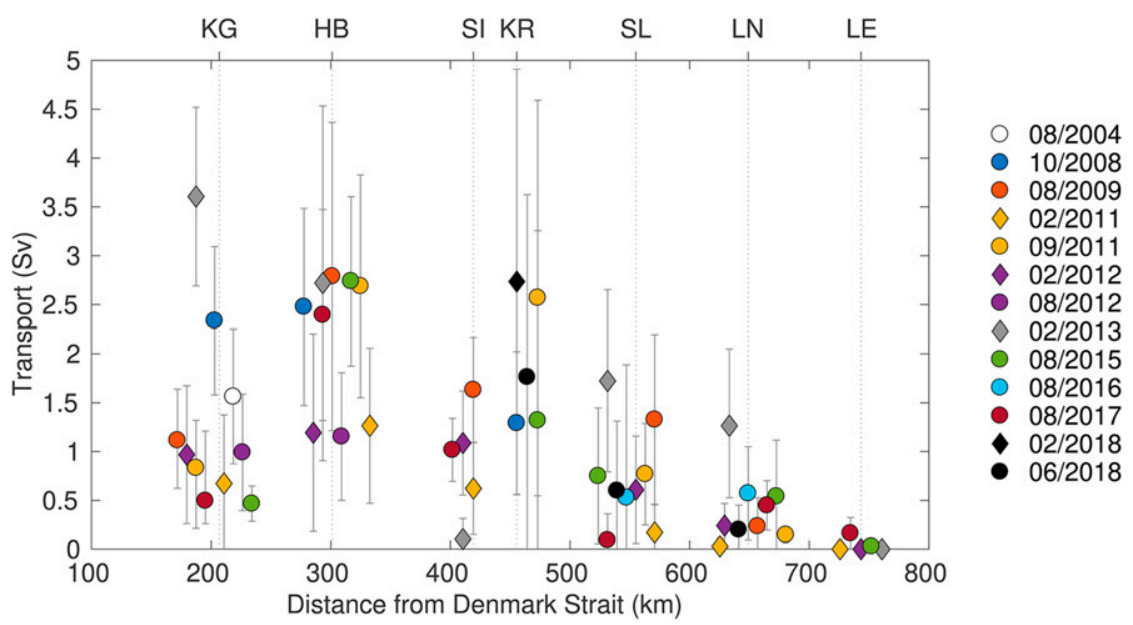

FIG. 12. Volume transport of overflow water in the NIJ and its uncertainty for all occupations and transects. Outer cores which were not fully resolved by the observations were doubled (see text). The survey years are color-coded, and winter occupations are marked by diamonds. For better legibility, estimates for the same transect are plotted adjacent to each other. The acronyms are: $\mathrm{KG}=$ Kögur, $\mathrm{HB}=$ Hornbanki, $\mathrm{SI}=$ Siglunes, $\mathrm{KR}=$ Kolbeinsey Ridge, $\mathrm{SL}=$ Slétta, LN = Langanes Northeast, and LE = Langanes East.

at the offshore end of the Siglunes transect, which has a north-south orientation, would not be accounted for since the absolute geostrophic velocity fields that the transports are calculated from are normal to the section. As noted above, a southward flow was also observed at a mooring located at the $1000-\mathrm{m}$ isobath on the western side of the Kolbeinsey Ridge (Jónsson and Valdimarsson 2012a). It is possible that this flow is the separated part of the NIJ forced into deeper water due to the curvature of the ridge. The importance of the sharp curvature of the Kolbeinsey Ridge is also apparent from the flow pattern across the ridge (Fig. 4d). After following the bathymetry northward along the slope, the NIJ broadens when crossing the ridge and the double-core structure becomes less defined, likely due to the curvature effect. The separation of the current after crossing the ridge might reestablish the double-core structure of the NIJ and thus could explain the existence of the offshore core at the Hornbanki section, which was observed in six of the nine occupations (section 4).

Another aspect of the NIJ negotiating the Kolbeinsey Ridge pertains to flow observed on the shelf. As mentioned in section $2 \mathrm{a}$, there was a transect situated just east of the ridge ( $14 \mathrm{~km}$ west of the Slétta transect). The continental shelf at this transect, and at the Siglunes transect, is deeper than $300 \mathrm{~m}$ - the only two survey lines where this is true. Recall that the maximum velocity of the NIJ is situated vertically in the water column near this depth. It is thus possible that some portion of the NIJ takes a direct route along the shelf instead of flowing around the Kolbeinsey Ridge. Unfortunately, the occupations of these two transects do not coincide in time, so we cannot make inferences about the continuity of this flow. Further work is required to understand precisely how the NIJ progresses past the Kolbeinsey Ridge, although our data indicate that the current clearly transports overflow water from the east side of the ridge to the west side of the ridge.

\section{Variability}

The volume transport of the NIJ varies substantially both within and between the surveys. This is seen by plotting the individual transport values for all of the occupations following the inclusive approach (Fig. 12). The large scatter motivates us to explore possible forcing mechanisms that could influence the current's transport over different time scales.

\section{a. Seasonal variability}

While our dataset consists predominantly of summer occupations (Table 1), there is nonetheless no apparent difference in NIJ transport between summer and winter (Fig. 12). Both large and small transports occur in winter relative to the mean at most transects. This lack of seasonality agrees with transport time series from moorings as well as numerical simulations. Harden et al. (2016) reported a slight reduction in the NIJ transport in winter and spring from the 1-yr mooring array at Kögur, while Huang et al. (2019) found no consistent seasonal cycle from a 2-yr mooring deployed 


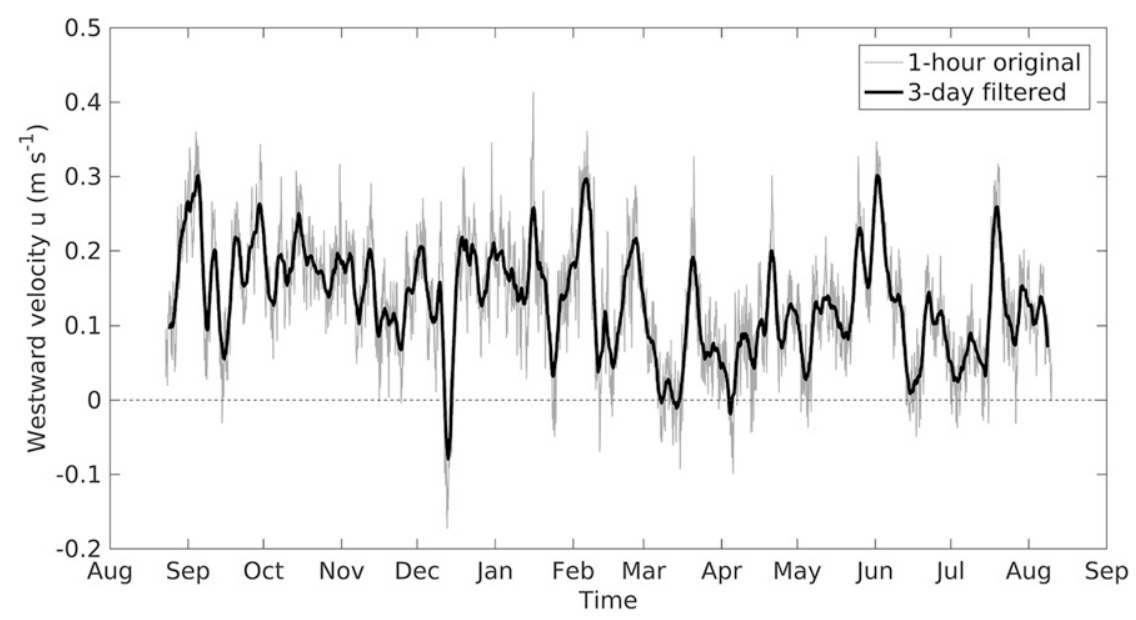

FIG. 13. Time series of de-tided velocity in the NIJ for the period of the mooring deployment (August 2005-August 2006) at the Hornbanki transect west of the Kolbeinsey Ridge (see Fig. 2 for the location of the mooring). The hourly and 3-day filtered time series are shown by the thin gray and thick black line, respectively.

in the NIJ at the same location. This agrees with velocity time series from three years of moored current meters on the Iceland slope of the Kögur transect (Jónsson 1999). Similarly, the transport of the NIJ did not have a seasonal cycle in the high-resolution numerical simulations of Behrens et al. (2017). Seasonal variability appears to be negligible farther upstream at the Hornbanki transect as well, and farther downstream at Denmark Strait. Neither the velocity time series in the core of the NIJ from the Hornbanki mooring (Fig. 13), nor longterm observations of the overflow plume (Jochumsen et al. 2017), reveal a seasonal cycle.

Regarding the hydrographic properties of the NIJ, we cannot identify distinct seasonal differences at any transect when comparing summer and winter subsets of Figs. 5 and 6 (not shown). The lack of a seasonal cycle is also reflected in the quantitative analysis of the individual cores of the NIJ (section 4). This corroborates the results of Mastropole et al. (2017) who found neither a seasonal cycle in the Arctic-origin water at Denmark Strait nor a seasonality in the occurrence of the boluses of Arctic-origin water passing through the strait. Our hydrographic sections reveal a seasonal change only near the surface, within the NIIC. As previously pointed out by Pickart et al. (2017), the water on the shelf is warmer, saltier, and more strongly stratified in summer than in winter. The NIIC varies seasonally in transport also, exhibiting a transport maximum in summer and a minimum in late spring, as other observations (Jónsson and Valdimarsson 2012b) and numerical simulations (Zhao et al. 2018) show. The seasonality in the NIIC is a result of changes in the atmospheric forcing (Logemann and Harms 2006; Zhao et al. 2018), which leads us to investigate if atmospheric forcing may play a role in the variability of the NIJ on other time scales.

\section{b. Atmospheric forcing}

\section{1) Mesoscale Variability}

Harden et al. (2016) found that, while the transports of the surface-intensified shelfbreak and separated EGC vary in time, the changes largely compensate each other. They argued that this variability is controlled by the across-stream gradient in the local wind through Denmark Strait. Here we investigate the possible effect of the wind on the mesoscale variability in the middepthintensified NIJ using the moored record in the center of the current at the Hornbanki transect (Fig. 13; section 2b). The westward speed was on average $13 \mathrm{~cm} \mathrm{~s}^{-1}$, ranging between a maximum of $41 \mathrm{~cm} \mathrm{~s}^{-1}$ in September and a minimum of $-17 \mathrm{~cm} \mathrm{~s}^{-1}$ in December. The latter event was unique in that the current reversed its direction for approximately four days.

Using the ERA-Interim reanalysis data (section 2c), we investigate the atmospheric conditions before, during, and after weakening and strengthening events of the NIJ at Hornbanki. The events are defined as times when the velocity from the moored record either exceeded or fell short of a certain threshold (such as a defined velocity, a local maximum, or a gradient). The exact magnitude of this threshold did not affect the results substantially. While a high pressure system south of Iceland induced southerly wind through Denmark Strait against the flow direction of the NIJ during the strong reversal event noted above, similar wind anomalies occurred without weakening the NIJ in a consistent 
way. Similarly, we did not detect any relation between strengthening events of the NIJ and the atmospheric conditions. We thus conclude that, despite the coincidence of the extended current reversal and the strong southerly storm, there was no consistent mesoscale response of the NIJ at Hornbanki to atmospheric forcing southwest of Iceland and in Denmark Strait during the period of the mooring deployment.

\section{2) LONG-TERM VARIABILITY}

While the compensation in volume transport of the separated and shelfbreak branches of the EGC has only been observed on short time scales (Harden et al. 2016), numerical simulations suggest that the two current branches vary out of phase on seasonal to interannual time scales as well. Behrens et al. (2017) argued that the local wind stress curl pattern substantially affects the EGC, which results in variability in the net volume transport of the combined branches across the Kögur transect on interannual time scales. They did not, however, find a clear response of the NIJ or the NIIC to changes in the wind stress curl. By contrast, in the numerical model used by Zhao et al. (2018), the wind stress southwest of Iceland impacted the transport of Atlantic Water in the NIIC. Furthermore, Pickart et al. (2017) argued that interannual changes in salinity of the NIIC and NIJ are linked through the wind stress curl in the subpolar gyre. Changes in wind stress curl have also been tied to varying sources of dense water advected into Denmark Strait. In the model study of Köhl (2010), strong positive wind stress curl around Iceland caused the EGC to be the main source of overflow water to Denmark Strait, whereas the Iceland Sea was the dominant source when the wind stress curl was weakly positive. De Jong et al. (2018) suggested that the strong wind stress curl during their RAFOS float deployment period may have been the reason why the NIJ appeared weak or absent in the float trajectories.

To investigate the effect of wind on interannual time scales, we identified surveys with consistently strong or weak NIJ transport and assessed the corresponding wind stress curl fields around Iceland, following the approach of de Jong et al. (2018, see their Fig. 9). In particular, we determined the occupations with abovemedian and below-median transports for each survey. (The median transport was used at each transect to account for the general increase in transport toward Denmark Strait.) Only one survey could be considered to have an overall weak NIJ (February 2011, where all five transects had transports below the median). Conversely, only two surveys had a relatively strong NIJ (February 2013 and August 2009, where four of five transects had transports above the median). All three surveys were conducted during periods of wind stress curl near its climatological mean value according to the atmospheric time series of de Jong et al. (2018), so we do not see a difference in wind stress curl between surveys with a weak and a strong NIJ, and, most often, there was no overall weak or strong NIJ. As such, our observations clearly do not support the hypothesis that the wind stress curl controls the strength of the NIJ on interannual time scales.

\section{c. Internal variability}

It has long been known that the overflow at Denmark Strait is highly variable on periods of a few days to a week (Aagaard and Malmberg 1978; Ross 1978; Macrander et al. 2007; Jochumsen et al. 2017; von Appen et al. 2017). Different configurations of the overflow have been identified, including the large boluses mentioned above, as well as another common scenario where the overflow layer thins and accelerates (referred to as pulses; von Appen et al. 2017). It has been argued that the dominant driver of this high-frequency variability is baroclinic instability (Smith 1976; Spall et al. 2019). Upstream of the sill, Håvik et al. (2017b) showed that the EGC is subject to baroclinic instability in winter, and suggested that this may be a source of the high-frequency variability in Denmark Strait. Regarding the NIJ, Harden and Pickart (2018) demonstrated that energetic topographic Rossby waves, with a dominant period of 3.6 days, are present at the Kögur site. They argued that the source of the waves is the meandering separated EGC seaward of the NIJ. Huang et al. (2019) calculated a significant conversion of potential energy from the mean to the eddies at the same site, indicative of baroclinic instability. Using our shipboard data, we now consider internal variability of the NIJ.

\section{1) BAROTROPIC INSTABILITY}

Barotropic instability is generally caused by strong horizontal velocity gradients, although it can be suppressed by steep bathymetry (von Appen et al. 2016). Eddies resulting from these instabilities extract kinetic energy from the mean flow and transport momentum down the lateral velocity gradient (Spall et al. 2008). A necessary criterion for barotropic instability to occur is that $\beta-\left(\partial^{2} u / \partial y^{2}\right)$ changes sign somewhere in the domain (e.g., Cushman-Roisin and Beckers 2011). The topographic $\beta$ effect is represented by $\beta=-(f / H)(\partial H / \partial y)$, where $f$ denotes the Coriolis parameter and $H$ depth. The bathymetric slopes in our study area yield relatively large values of $\beta=O\left(10^{-8}\right)$. We compared this to $u_{y y}=\partial^{2} u / \partial y^{2}$ for each current core. For example, at the Hornbanki transect west of the Kolbeinsey Ridge, the along-stream 
velocity $u$ is on average $16 \mathrm{~cm} \mathrm{~s}^{-1}$ with current widths of order $16 \mathrm{~km}$. This means that $u_{y y}$ is of the same order of magnitude as $\beta$. The same result holds for the majority of the transects. Therefore, the necessary-but not sufficient-condition for barotropic instability is fulfilled for the NIJ.

\section{2) BAROCLINIC INSTABILITY}

Baroclinic instability is generally facilitated by strong vertical shear of the horizontal velocity, whereas it can be suppressed by a strong stratification (von Appen et al. 2016). Resulting eddies extract the available potential energy from the mean field and transport this energy down the mean lateral density gradient (Spall et al. 2008). A necessary condition for baroclinic instability to occur is that the horizontal gradient of the total potential vorticity changes sign with depth (e.g., Spall et al. 2008). The Ertel potential vorticity is the sum of the planetary stretching term, the relative vorticity, and the tilting vorticity (e.g., Pickart et al. 2005; Spall et al. 2008). We find that the stretching term is the dominant contribution to the total potential vorticity. As such, we can simplify the Ertel potential vorticity $(\mathrm{PV})$ to $\mathrm{PV} \approx-\left(f / \rho_{0}\right)(\partial \rho / \partial z)$, where $\rho_{0}$ is the background potential density. The vertical sections of PV for the individual occupations of the different transects yield the consistent result that the horizontal gradient of PV reverses sign with depth. Therefore, the necessary criterion for baroclinic instability is also fulfilled for the NIJ.

These results imply that some of the observed variability in structure and transport of the NIJ may be due to internal variability in the form of both barotropic and baroclinic instability. We note that such high-frequency fluctuations could make it more difficult to infer responses of the NIJ to atmospheric forcing; continued measurements of the current will hopefully make this easier. The internal variability in the NIJ requires further investigation and will be the subject of future work.

\section{Summary and conclusions}

In this study we used high-resolution hydrographic/ velocity measurements from 13 surveys along the slope north of Iceland to characterize and quantify the properties and transport of the NIJ for the first time along its entire path. The current emerges northeast of Iceland and crosses the Kolbeinsey Ridge, an extension of the mid-Atlantic Ridge north of Iceland. Near Denmark Strait the NIJ merges with the separated EGC, and from that point onward it cannot be distinguished as a distinct current. Our results demonstrate that the NIJ represents an important contribution to the Denmark Strait overflow.
The current displays a double-core structure that is present both east and west of the Kolbeinsey Ridge at roughly $50 \%$ of all occupations. The inner core is generally found at the $600-\mathrm{m}$ isobath, while the outer core is located farther downslope at the $800-\mathrm{m}$ isobath. It is presently unclear whether the outer core is a separate component of the current or if it is related to eddies or wave activity. Harden and Pickart (2018) demonstrated that topographic Rossby waves on the Iceland slope cause high-frequency variability in the NIJ signature at the Kögur site, but whether these or other waves also exist farther upstream remains to be determined. Here we considered the outer core to be an integral part of the current and included it in the transport estimates.

The volume transport of overflow water in the NIJ, which comprises on average $90 \%$ of the total transport of the current, increased by approximately $0.4 \mathrm{~Sv}$ per $100 \mathrm{~km}$ along the current's path until the Hornbanki transect, roughly $300 \mathrm{~km}$ upstream of Denmark Strait. This gradual increase is consistent with the model results of Våge et al. (2011) which suggest that the current is fed by sinking of dense water along the entire north slope of Iceland. The water transported by the NIJ is mainly of Arctic origin, with the coldest and densest portion banked up against the continental slope. The bulk of the volume transport is confined to a small area in $\Theta-S$ space centered near $-0.29^{\circ} \pm 0.16^{\circ} \mathrm{C}$ in temperature and $35.075 \pm 0.006 \mathrm{~g} \mathrm{~kg}^{-1}$ in salinity, corresponding to a density of $\sigma_{\theta}=28.05 \mathrm{~kg} \mathrm{~m}^{-3}$. The hydrographic properties of this transport mode do not change significantly along the current's path, which indicates that the mode is largely unaffected by entrainment of warmer, ambient waters. This densest portion of the NIJ most likely stems from the Greenland Sea, where sufficiently dense waters are regularly formed (Brakstad et al. 2019). However, the exact pathways between the Greenland and Iceland Seas remain unknown.

Comparing the volume transport of the NIJ to the transport estimated from the year-long mooring array at the Kögur transect $(1.00 \pm 0.17 \mathrm{~Sv}$; Harden et al. 2016), we found a higher mean transport of $1.3 \pm 0.2 \mathrm{~Sv}$ for both the conservative and inclusive estimates. Some of this discrepancy is likely due to the different types of measurements (multiple realizations per day for a year versus our 10 occupations over 13 years) and the different methods of estimating transport (the different approach for assigning current boundaries and the consideration of net flow versus equatorward flow). Extracting periods from the gridded mooring sections when the NIJ is clearly distinct from the EGC, we found a transport of $1.7 \pm 0.2 \mathrm{~Sv}$. This result agrees well with the transport of the NIJ at the Hornbanki transect farther upstream, where it is at least $1.8 \pm 0.3 \mathrm{~Sv}$ and more likely 
$2.2 \pm 0.4 \mathrm{~Sv}$ according to the conservative and inclusive estimates, respectively. This suggests that when the currents are distinct at the Kögur transect, the contribution from the NIJ is higher than when the currents have merged and some of the NIJ transport may have been entrained into the separated EGC, appearing to lower the NIJ transport. We therefore argue that the contribution of water from the NIJ to the Denmark Strait overflow is higher than previously envisaged.

The variability in volume transport between and within the surveys was substantial. On short time scales, no direct link between the variability of the NIJ and the local wind could be identified. While a current reversal observed in the moored record at the Hornbanki transect coincided with anomalously strong southerly wind through Denmark Strait, no consistent response to similar atmospheric patterns was found. Similarly, no clear seasonal variability of the NIJ was detected, in agreement with previous observational and modeling results (Harden et al. 2016; Behrens et al. 2017).

On longer time scales, it has been hypothesized that the wind stress curl around Iceland affects the strength of the NIJ (Köhl 2010; de Jong et al. 2018). However, no clear link between the wind stress curl and the strength of the NIJ could be established from our observations. The most likely explanation for the variability in our transport estimates is internal forcing, as the necessary conditions for both barotropic and baroclinic instability are fulfilled in the NIJ.

This study, by characterizing and quantifying the alongstream evolution of the NIJ, provides the basis for future dynamical investigations addressing the formation and variability of the current. Our comprehensive dataset has definitively confirmed that the NIJ emerges northeast of Iceland, is fed by a continuous supply of dense water along the current's entire pathway, and is a main source of DSOW into Denmark Strait. The NIJ thus constitutes a fundamental component of the overturning in the Nordic Seas that needs to be accounted for when considering the response of the AMOC to varying climate forcing.

Acknowledgments. Six different research vessels were involved in the collection of the data used in this study: RRS James Clark Ross, R/V Knorr, R/V Bjarni Samundsson, R/V Håkon Mosby, NRV Alliance, and $\mathrm{R} / \mathrm{V}$ Kristine Bonnevie. We thank the captain and crew of each of these vessels for their hard work as well as the many watch standers who have sailed on the cruises and helped collect the measurements. We also thank Frank Bahr for processing the VMADCP data collected on NRV Alliance and Magnús Danielsen for the processing of the hydrographic data collected on R/V Bjarni Samundsson. We acknowledge Leah
Trafford McRaven for assistance with Fig. 1 and two anonymous reviewers for their helpful comments, which improved the manuscript. Funding for the project was provided by the Bergen Research Foundation Grant BFS2016REK01 (K. Våge and S. Semper), the Norwegian Research Council under Grant Agreement 231647 (K. Våge), and the U.S. National Science Foundation Grants OCE-1259618 and OCE-1756361 (R. S. Pickart and D. J. Torres), as well as OCE-1558742 (R. S. Pickart). The dataset is available on PANGAEA under https:// doi.pangaea.de/10.1594/PANGAEA.903535.

\section{REFERENCES}

Aagaard, K., and S. A. Malmberg, 1978: Low-frequency Characteristics of the Denmark Strait Overflow. ICES CM 1978/C:47, International Council for the Exploration of the Sea, $22 \mathrm{pp}$.

Almansi, M., T. W. N. Haine, R. S. Pickart, M. G. Magaldi, R. Gelderloos, and D. Mastropole, 2017: High-frequency variability in the circulation and hydrography of the Denmark Strait overflow from a high-resolution numerical model. J. Phys. Oceanogr., 47, 2999-3013, https://doi.org/10.1175/ JPO-D-17-0129.1.

Amante, C., and B. W. Eakins, 2009: ETOPO1 1 arc-minute global relief model: Procedures, data sources, and analysis. NOAA Tech. Memo. NESDIS NGDC-24, 25 pp., https://www.ngdc.noaa.gov/

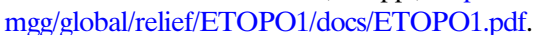

Behrens, E., K. Våge, B. Harden, A. Biastoch, and C. Böning, 2017: Composition and variability of the Denmark Strait Overflow Water in a high-resolution numerical model hindcast simulation. J. Geophys. Res. Oceans, 122, 2830-2846, https://doi.org/ 10.1002/2016JC012158.

Björk, G., and Coauthors, 2010: Flow of Canadian basin deep water in the Western Eurasian Basin of the Arctic Ocean. Deep-Sea Res. I, 57, 577-586, https://doi.org/10.1016/j.dsr.2010.01.006.

Bosse, A., P. Testor, L. Mortier, L. Prieur, V. Taillandier, F. D'Ortenzio, and L. Coppola, 2015: Spreading of Levantine Intermediate Waters by submesoscale coherent vortices in the northwestern Mediterranean Sea as observed with gliders. J. Geophys. Res. Oceans, 120, 1599-1622, https://doi.org/ 10.1002/2014JC010263.

Brakstad, A., K. Våge, L. Håvik, and G. W. K. Moore, 2019: Water mass transformation in the Greenland Sea during the period 1986-2016. J. Phys. Oceanogr., 49, 121-141, https://doi.org/ 10.1175/JPO-D-17-0273.1.

Cooper, L. H. N., 1955: Deep water movements in the North Atlantic as a link between climatic changes around Iceland and biological productivity of the English Channel and Celtic Sea. J. Mar. Res., 14 (4), 347-362.

Cushman-Roisin, B., and J.-M. Beckers, 2011: Physical and Numerical Aspects. 2nd ed. Introduction to Geophysical Fluid Dynamics, Vol. 101, Academic Press, 845 pp.

Dee, D. P., and Coauthors, 2011: The ERA-Interim reanalysis: Configuration and performance of the data assimilation system. Quart. J. Roy. Meteor. Soc., 137, 553-597, https://doi.org/ 10.1002/qj.828.

de Jong, M. F., H. Søiland, A. S. Bower, and H. H. Furey, 2018: The subsurface circulation of the Iceland Sea observed with RAFOS floats. Deep-Sea Res. I, 141, 1-10, https://doi.org/ 10.1016/j.dsr.2018.07.008. 
Dickson, R. R., and J. Brown, 1994: The production of North Atlantic Deep Water: Sources, rates, and pathways. J. Geophys. Res., 99, 12 319-12 341, https://doi.org/10.1029/94JC00530.

Egbert, G. D., and S. Y. Erofeeva, 2002: Efficient inverse modeling of barotropic ocean tides. J. Atmos. Oceanic Technol., 19, 183-204, https://doi.org/10.1175/1520-0426(2002)019<0183: EIMOBO $>2.0 . \mathrm{CO} ; 2$.

Eldevik, T., J. E. Ø. Nilsen, D. Iovino, K. Anders Olsson, A. B. Sand $\varnothing$, and H. Drange, 2009: Observed sources and variability of Nordic seas overflow. Nat. Geosci., 2, 406-410, https:// doi.org/10.1038/ngeo518.

Emery, W. J., and R. E. Thomson, 2014: Data Analysis Methods in Physical Oceanography. 3rd ed., Elsevier, 728 pp.

Firing, E., and J. M. Hummon, 2010: Shipboard ADCP measurements. IOCCP Rep. 14, ICPO Publication Series 134, International CLIVAR Project Office, 11 pp., http://www.go-ship.org/Manual/ Firing_SADCP.pdf.

Harden, B. E., and Coauthors, 2016: Upstream sources of the Denmark Strait Overflow: Observations from a high-resolution mooring array. Deep-Sea Res. I, 112, 94-112, https://doi.org/10.1016/ j.dsr.2016.02.007.

— North Icelandic Jet. J. Mar. Res., 76, 47-62, https://doi.org/ 10.1357/002224018824845910.

— I. A. Renfrew, and G. N. Petersen, 2011: A climatology of wintertime barrier winds off southeast Greenland. J. Climate, 24, 4701-4717, https://doi.org/10.1175/2011JCLI4113.1.

Håvik, L., R. S. Pickart, K. Våge, D. J. Torres, A. M. Thurnherr, A. Beszczynska-Möller, W. Walczowski, and W. J. von Appen, 2017a: Evolution of the East Greenland Current from Fram Strait to Denmark Strait: Synoptic measurements from summer 2012. J. Geophys. Res. Oceans, 122, 1974-1999, https:// doi.org/10.1002/2016JC012228.

_ , K. Våge, R. S. Pickart, B. Harden, W. J. von Appen, S. Jónsson, and S. Østerhus, 2017b: Structure and variability of the shelfbreak East Greenland Current north of Denmark Strait. J. Phys. Oceanogr., 47, 2631-2646, https://doi.org/ 10.1175/JPO-D-17-0062.1.

Huang, J., R. S. Pickart, H. Valdimarsson, P. Lin, M. A. Spall, and F. Xu, 2019: Structure and variability of the North Icelandic Jet from two years of mooring data. J. Geophys. Res. Oceans, 124, 3987-4002, https://doi.org/10.1029/2019jc015134.

IOC, SCOR, and IAPSO, 2010: The international thermodynamic equation of seawater - 2010: Calculation and use of thermodynamic properties. Intergovernmental Oceanographic Commission, Manuals and Guides 56, UNESCO, 196 pp., http:// www.teos-10.org/pubs/TEOS-10_Manual.pdf.

Jeansson, E., S. Jutterström, B. Rudels, L. G. Anderson, K. Anders Olsson, E. P. Jones, W. M. Smethie, and J. H. Swift, 2008: Sources to the East Greenland Current and its contribution to the Denmark Strait Overflow. Prog. Oceanogr., 78, 12-28, https://doi.org/10.1016/j.pocean.2007.08.031.

Jochumsen, K., M. Moritz, N. Nunes, D. Quadfasel, K. M. Larsen, B. Hansen, H. Valdimarsson, and S. Jónsson, 2017: Revised transport estimates of the Denmark Strait overflow. J. Geophys. Res. Oceans, 122, 3434-3450, https://doi.org/10.1002/2017JC012803.

Jónsson, S., 1999: The circulation in the northern part of the Denmark Strait and its variability. ICES CM 1999/L:06, International Council for the Exploration of the Sea, 9 pp., http://www.ices.dk/ sites/pub/CM\%20Doccuments/1999/L/L0699.pdf.

-, and H. Valdimarsson, 2004: A new path for the Denmark Strait overflow water from the Iceland Sea to Denmark Strait. Geophys. Res. Lett., 31, L03305, https://doi.org/10.1029/2003GL019214.
— , and —-, 2012a: Hydrography and circulation over the southern part of the Kolbeinsey Ridge. ICES J. Mar. Sci., 69, 1255-1262, https://doi.org/10.1093/icesjms/fss101.

— and - 2012b: Water mass transport variability to the North Icelandic shelf, 1994-2010. ICES J. Mar. Sci., 69, 809-815, https://doi.org/10.1093/icesjms/fss024.

Köhl, A., 2010: Variable source regions of Denmark Strait and Faroe Bank Channel overflow waters. Tellus, 62A, 551-568, https://doi.org/10.1111/j.1600-0870.2010.00454.x.

— , R. H. Käse, D. Stammer, and N. Serra, 2007: Causes of changes in the Denmark Strait Overflow. J. Phys. Oceanogr., 37, 1678-1696, https://doi.org/10.1175/JPO3080.1.

Logemann, K., and I. Harms, 2006: High resolution modelling of the North Icelandic Irminger Current (NIIC). Ocean Sci., 2 , 291-304, https://doi.org/10.5194/os-2-291-2006.

Macrander, A., R. H. Käse, U. Send, H. Valdimarsson, and S. Jónsson, 2007: Spatial and temporal structure of the Denmark Strait Overflow revealed by acoustic observations. Ocean Dyn., 57, 75-89, https://doi.org/10.1007/s10236-007-0101-x.

Marshall, D., and C. E. Tansley, 2001: An implicit formula for boundary current separation. J. Phys. Oceanogr., 31, 16331638, https://doi.org/10.1175/1520-0485(2001)031<1633:AIFFBC> 2.0.CO;2.

Mastropole, D., R. S. Pickart, H. Valdimarsson, K. Våge, K. Jochumsen, and J. B. Girton, 2017: On the hydrography of Denmark Strait. J. Geophys. Res. Oceans, 122, 306-321, https:// doi.org/10.1002/2016JC012007.

Mauritzen, C., 1996: Production of dense overflow waters feeding the North Atlantic across the Greenland-Scotland Ridge. Part 1: Evidence for a revised circulation scheme. Deep-Sea Res., 43, 769-806, https://doi.org/10.1016/09670637(96)00037-4.

Messias, M. J., and Coauthors, 2008: The Greenland Sea tracer experiment 1996-2002: Horizontal mixing and transport of Greenland Sea Intermediate Water. Prog. Oceanogr., 78, 85-105, https://doi.org/10.1016/j.pocean.2007.06.005.

Nurser, A. J. G., and S. Bacon, 2014: The Rossby radius in the Arctic Ocean. Ocean Sci., 10, 967-975, https://doi.org/10.5194/ os-10-967-2014.

Østerhus, S., and Coauthors, 2019: Arctic Mediterranean exchanges: A consistent volume budget and trends in transports from two decades of observations. Ocean Sci., 15, 379-399, https://doi.org/10.5194/os-15-379-2019.

Pawlowicz, R., B. Beardsley, and S. Lentz, 2002: Classical tidal harmonic analysis including error estimates in MATLAB using T_TIDE. Comput. Geosci., 28, 929-937, https://doi.org/ 10.1016/S0098-3004(02)00013-4.

Pickart, R. S., and W. M. Smethie, 1998: Temporal evolution of the Deep Western Boundary Current where it enters the subtropical domain. Deep-Sea Res. I, 45, 1053-1083, https:// doi.org/10.1016/S0967-0637(97)00084-8.

_ D. J. Torres, and P. S. Fratantoni, 2005: The East Greenland Spill Jet. J. Phys. Oceanogr., 35, 1037-1053, https://doi.org/ 10.1175/JPO2734.1.

_ - and Coauthors, 2017: The North Icelandic Jet and its relationship to the North Icelandic Irminger Current. J. Mar. Res., 75, 605-639, https://doi.org/10.1357/002224017822109505.

Ross, C. K., 1978: Overflow variability in Denmark Strait. ICES J. Mar. Sci., 21, 1-9.

Rudels, B., E. Fahrbach, J. Meincke, G. Budéus, and P. Ericksson, 2002: The East Greenland Current and its contribution to the Denmark Strait overflow. ICES J. Mar. Sci., 59, 1133-1154, https://doi.org/10.1006/jmsc.2002.1284. 
Smith, P. C., 1976: Baroclinic instability in the Denmark Strait Overflow. J. Phys. Oceanogr., 6, 355-371, https://doi.org/ 10.1175/1520-0485(1976)006<0355:BIITDS > 2.0.CO;2.

Spall, M. A., R. S. Pickart, P. S. Fratantoni, and A. J. Plueddemann, 2008: Western Arctic shelfbreak eddies: Formation and transport. J. Phys. Oceanogr., 38, 1644-1668, https://doi.org/ 10.1175/2007JPO3829.1.

_ J. Pedlosky, and C. Cenedese, 2017: Circulation induced by isolated dense water formation over closed topographic contours. J. Phys. Oceanogr., 47, 2251-2265, https://doi.org/ 10.1175/JPO-D-17-0042.1.

—, R. S. Pickart, P. Lin, H. Valdimarsson, T. W. N. Haine, and M. Almansi, 2019: Frontogenesis and variability in Denmark Strait and its influence on overflow water. J. Phys. Oceanogr. 49, 1889-1904, https://doi.org/10.1175/JPO-D-19-0053.1.

Strass, V. H., E. Fahrbach, U. Schauer, and L. Sellmann, 1993: Formation of Denmark Strait overflow water by mixing in the East Greenland Current. J. Geophys. Res., 98, 6907-6919, https://doi.org/10.1029/92JC02732.

Swift, J. H., and K. Aagaard, 1981: Seasonal transitions and water mass formation in the Iceland and Greenland seas. Deep-Sea Res. I, 28, 1107-1129, https://doi.org/10.1016/0198-0149(81) 90050-9.

- _ - and S. A. Malmberg, 1980: The contribution of the Denmark Strait overflow to the deep North Atlantic. DeepSea Res. I, 27, 29-42, https://doi.org/10.1016/0198-0149(80) 90070-9.

Tanhua, T., K. Bulsiewicz, and M. Rhein, 2005: Spreading of overflow water from the Greenland to the Labrador Sea. Geophys. Res. Lett., 32, L10605, https://doi.org/10.1029/2005GL022700.

Thurnherr, A. M., 2010: A practical assessment of the errors associated with full-depth LADCP profiles obtained using Teledyne RDI Workhorse acoustic Doppler current profilers. J. Atmos. Oceanic Technol., 27, 1215-1228, https://doi.org/10.1175/ 2010JTECHO708.1.

- 2018: How to process LADCP data with the LDEO software. User manual, Columbia University, 32 pp., https:// www.ldeo.columbia.edu/ ant/LADCP.html.
Våge, K., R. S. Pickart, M. A. Spall, H. Valdimarsson, S. Jónsson, D. J. Torres, S. Østerhus, and T. Eldevik, 2011: Significant role of the North Icelandic Jet in the formation of Denmark Strait overflow water. Nat. Geosci., 4, 723-727, https:// doi.org/10.1038/ngeo1234

G. W. K. Moore, H. Valdimarsson, D. J. Torres, S. Y. Erofeeva, and J. E. Ø. Nilsen, 2013: Revised circulation scheme north of the Denmark Strait. Deep-Sea Res. I, 79, 20-39, https://doi.org/10.1016/j.dsr.2013.05.007.

—, G. W. K. Moore, S. Jónsson, and H. Valdimarsson, 2015: Water mass transformation in the Iceland Sea. Deep-Sea Res. I, 101, 98-109, https://doi.org/10.1016/j.dsr.2015.04.001.

—, L. Papritz, L. Håvik, M. A. Spall, and G. W. K. Moore, 2018: Ocean convection linked to the recent ice edge retreat along east Greenland. Nat. Commun., 9, https://doi.org/10.1038/ s41467-018-03468-6.

von Appen, W. J., U. Schauer, T. Hattermann, and A. BeszczynskaMöller, 2016: Seasonal cycle of mesoscale instability of the West Spitsbergen Current. J. Phys. Oceanogr., 46, 1231-1254, https:// doi.org/10.1175/JPO-D-15-0184.1.

, D. Mastropole, R. S. Pickart, H. Valdimarsson, S. Jónsson, and J. B. Girton, 2017: On the nature of the mesoscale variability in Denmark Strait. J. Phys. Oceanogr., 47, 567-582, https://doi.org/10.1175/JPO-D-16-0127.1.

Yang, J., and L. Pratt, 2014: Some dynamical constraints on upstream pathways of the Denmark Strait Overflow. J. Phys. Oceanogr., 44, 3033-3053, https://doi.org/10.1175/JPO-D-13-0227.1.

Ypma, S. L., N. Brüggemann, S. Georgiou, P. Spence, H. A. Dijkstra, J. D. Pietrzak, and C. A. Katsman, 2019: Pathways and watermass transformation of Atlantic Water entering the Nordic Seas through Denmark Strait in two high resolution ocean models. Deep-Sea Res. I, 145, 59-72, https://doi.org/10.1016/ j.dsr.2019.02.002.

Zhao, J., J. Yang, S. Semper, R. S. Pickart, K. Våge, H. Valdimarsson, and S. Jónsson, 2018: A numerical study of interannual variability in the North Icelandic Irminger Current. J. Geophys. Res. Oceans, 123, 8994-9009, https:// doi.org/10.1029/2018JC013800. 